\title{
Maximum Total Organic Carbon Limits At Different DWPF Melter Feed Rates (U)
}

by

A. S. Choi

Westinghouse Savannah River Company

Savannah River Site

Aiken, South Carolina 29808

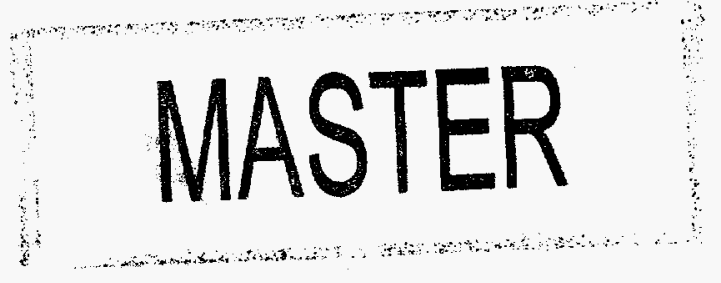

This paper was prepared in connection with work done under the above contract number with the U. S. Department of Energy. By acceptance of this paper, the publisher and/or recipient acknowledges the U.S. Government's right to retain a nonexclusive, royalty-free license in and to any copyright covering this paper, along with the right to reproduce and to authorize others to reproduce all or part of the copyrighted paper. 


\section{DISCLAMMER}

Portions of this document may be illegible in electronic image products. Images are produced from the best available original document. 


\section{DISCLAIMER}

This report was prepared as an account of work spoasored by an agency of the United States Government. Neither the United States Government nor any agency thereof, nor any of their employees, makes any warranty, express or implied. or assumes any legal liability or responsibility for the accuracy. completeness, or usefulness of any information, apparatus, product, or process disclosed, or represents that its use would not infringe privately owned rights. Reference herein to any specific commercial product, process, or service by trade name, trademark, manufacturer, or otherwise does not necessarily constitute or imply its endorsement, recommendation, or favoring by the United States Government or any agency thereof. The views and opinions of authors expressed herein do not necessarily state or reflect those of the United States -Government or any agency thereof.

This report has been reproduced directly from the best available copy.

Available to DOE and DOE contractors from the Office of Scientific and Technical Information, P. O. Box 62, Oak Ridge, TN 37831; prices available from (615) $576-8401$.

Available to the public from the National Technical Information Service, U. S. Department of Commerce, 5285 Port Royal Rd.. Springfield, VA 22161 
WSRC-TR-95-0294-TL (Revision 1)

January 15,1996

MAXIMUM TOTAL ORGANIC CARBON LIMITS AT

DIFFERENT DWPF MELTER FEED RATES (U)

Distribution:

D. B. Amerine, 704-S

S. F. Piccolo, 704-S

J. F. Ortaldo, 704-S

M. J. Montini, 704-S

J. T. Carter, 704-25S

R. E. Edwards, 704-25S

J. E. Owen, 704-30S

D. C. Iverson, 704-30S

W. S. Odom, 704-30S

J. P. Schwenker, 704-35S

D. C. Witt, 704-29S

D F. Gehr, 704-35S

W. A. Mangiante, 992-1W

L. M. Papouchado, 773-A

E. W. Holtzscheiter, 773-A

M. J. Plodinec, 773-A

L. F. Landon, 704-T

C. T. Randall, 704-T

R. A. Jacobs, 704-T

T. K. Snyder, 704-T

A. S. Choi, 704-1T (4)

SRTC Records, 773-52A (4) 
WESTINGHOUSE SAVANNAH RIVER COMPANY

SAVANNAH RIVER TECHNOLOGY CENTER

WSRC-TR-95-0294-TL

(Revision 1)

January 15,1996

Keywords: DWPF Melter, Total

Organic Carbon,

Feed Rate, LFL

Retention Period: Permanent

D. B. Amerine, Program Manager

Defense Waste Processing Facility

High Level Waste Management Division

Attention: S. F. Piccolo, 704-S

\section{MAXIMUM TOTAL ORGANIC CARBON LIMITS AT \\ DIFFERENT DWPF MELTER FEED RATES (U)}

The attached report by A. S. Choi is the Revision 1 of the report issued earlier concerning the total organic carbon (TOC) limits for the DWPF melter feed. It includes some format changes made to comply with the new site policy on the technical document control. No changes have been made to any of the technical contents of the Revision 0.

This revised report documents the results of a study to assess the impact of varying melter feed rates on the maximum TOC limits allowable in the DWPF melter feed, as stated in the Technical Task Request HLW/DWPF/TTR-950047. In order to minimize a potential for forming a flammable vapor in the melter off-gas system, the following correlation is recommended to determine the maximum TOC limit, including both formate and aromatic carbons, from a given feed rate and the specific gravity of the feed:

$$
\max \text { TOC }(p p m)=45,180^{*} F R^{*} S p G-108,200 \operatorname{Ln}\left(F R^{*} S p G\right)-4,860
$$

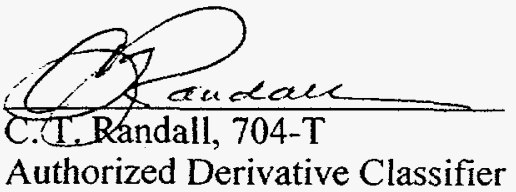


WSRC-TR-95-0294-TL

(Revision 1)

where FR is the feed rate in GPM ranging from 0.7 to $1.5 \mathrm{GPM}$, and $\mathrm{SpG}$ is the specific gravity. If it is desired to determine the highest feed rate that the DWPF melter can tolerate at a given TOC level measured in ppm, the following correlation is recommended:

$$
\begin{aligned}
\max \text { feed rate }(\mathrm{GPM})= & 0.756+1,185.5 \mathrm{Ln}\left(\mathrm{TOC}{ }^{\star} \mathrm{SpG}\right) /(\mathrm{TOC} * \mathrm{SpG}) \\
& -5.4 \mathrm{E}-6{ }^{*} \mathrm{TOC}{ }^{\star} \mathrm{SpG}
\end{aligned}
$$

At TOC levels below the maximum limit predicted from the above correlation for a given feed rate, the peak concentration of combustible gases in the quenched offgas will not exceed $60 \%$ of the lower flammable limit (LFL) during a $3 X$ off-gas surge, provided that a steady melter operation is established at the onset of surge, and the following operating conditions are met at all feed rates considered:

- The indicated melter vapor space temperature (TI-4085D) is maintained above $650^{\circ} \mathrm{C}$.

- The air purge to the backup film cooler (FIC-3221B) is maintained above $250 \mathrm{lb} / \mathrm{hr}$ including $30 \mathrm{lb} / \mathrm{hr}$ line purge.

- The total air purge to the melter (FIC-3221A) is maintained above $850 \mathrm{lb} / \mathrm{hr}$.

The peak magnitude of a $3 \mathrm{X}$ off-gas surge is 3 times nominal with an average magnitude of 2.25 times nominal for the first 1 minute, and the total duration of a surge is up to 8 minutes. At the reference DWPF melter feed rate of 0.9 GPM and a specific gravity of 1.48 , the maximum allowable TOC limit thus determined is about $24,000 \mathrm{ppm}$, and the maximum TOC feed rate is $15.8 \mathrm{lb} / \mathrm{hr}$ at $0.9 \mathrm{GPM}$.

All the necessary calculations for this study were made using the 4-stage cold cap model and the melter off-gas dynamics model. The 4-stage cold cap model was validated earlier against the melter data obtained using the formic acid flowsheet feed. With a more oxidizing feed under the current nitric acid flowsheet, use of this model is believed to be conservative. Nevertheless, it is recommended that this conservatism still be verified, and the model be calibrated by running a controlled experiment on the IDMS.

In addition, in view of recent DWPF melter cold run data, the $3 \mathrm{X}$ surge criteria used in this study, i.e., the 8 minute total surge duration with an average magnitude of 2.25 times nominal for the first 1 minute appear to be conservative. 
This conservatism will be verified during the upcoming dynamic simulation study which, along with this TOC study, will then satisfy all the requirements for the Technical Task Request HLW/DWPF/TTR-950047. All of the customer comments by R. E. Edwards of DWPF-Engineering have been resolved and incorporated into the attached report.

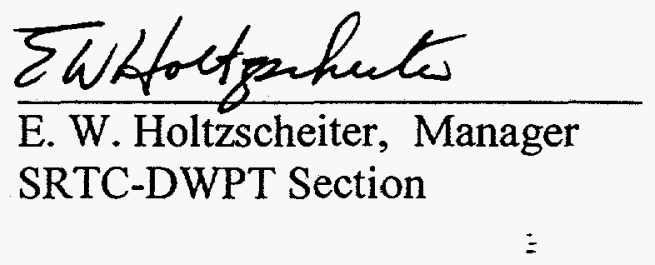


WSRC-TR-95-0294

(Revision 1)

Keywords: DWPF Melter, Total

Organic Carbon,

Feed Rate, LFL

Retention Period: Permanent

\title{
MAXIMUM TOTAL ORGANIC CARBON LIMITS AT DIFFERENT DWPF MELTER FEED RATES (U)
}

January 15, 1996

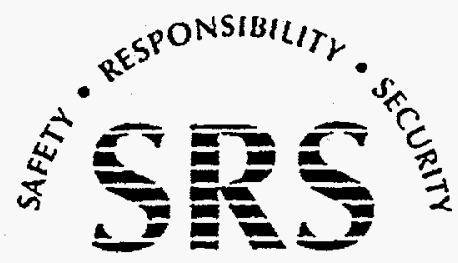

SAVANNAH RIVER SITE

\author{
Alexander S. Choi \\ Defense Waste Processing Technology \\ Savannah River Technology Center \\ Westinghouse Savannah River Company \\ Aiken, SC 29808
}




\section{DOCUMENT APPROVAL SHEET}

A. S. Choi, Author

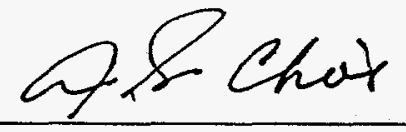

Defense Waste Processing Technology Section / SRTC

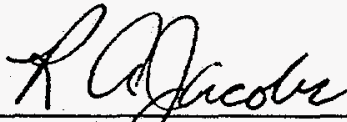

R. A. Jacbbs, Technical Reviewer

Defense Waste Processing Technology Section / SRTC

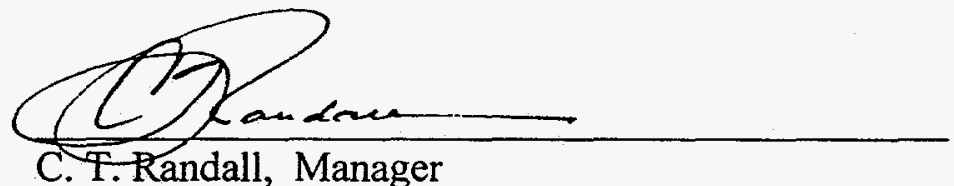

Process Modeling and Control Group, DWPT / SRTC

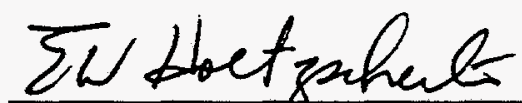

E. W. Holtzscheiter, Manager

Defense Waste Processing Technology Section/ SRTC

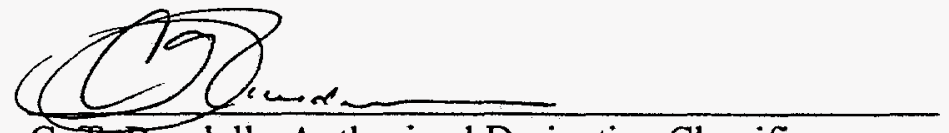

C.T. Randall, Authorized Derivative Classifier

Defense Waste Processing Technology Section/SRTC
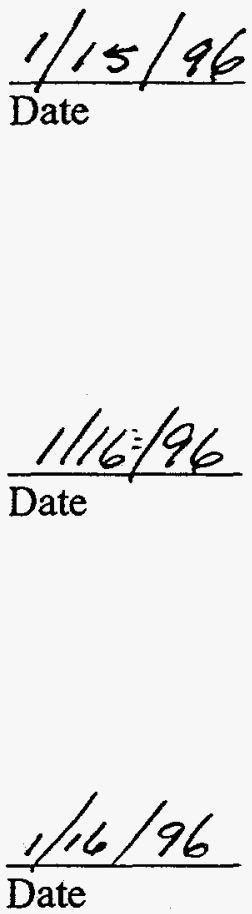

$\frac{1 / 22 / 36}{\text { Date }}$

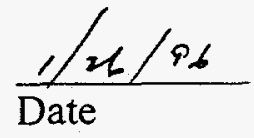




\section{SUMMARY}

As partial fulfillment of the Technical Task Request HLW/DWPF/TTR-950047 (DWPT Activity \# DWPT-95-0031), the maximum total organic carbon (TOC) limits that are allowable in the DWPF melter feed without forming a potentially flammable vapor in the off-gas system were determined at feed rates varying from 0.7 to 1.5 GPM. Given a feed rate and the specific gravity of the feed, the following correlation was developed to determine the maximum TOC level in the feed including both formate and aromatic carbons:

$$
\max \operatorname{TOC}(p p m)=45,180 * F R^{*} S p G-108,200 \operatorname{Ln}\left(F R^{*} S p G\right)-4,860
$$

where FR is the feed rate in GPM, and $\mathrm{SpG}$ is the specific gravity. If one needs to determine the highest feed rate that the DWPF melter can tolerate at a given TOC level measured in ppm, the following correlation can be used:

$$
\begin{aligned}
\max \text { feed rate }(\mathrm{GPM})= & 0.756+1,185.5 \mathrm{Ln}\left(\mathrm{TOC}{ }^{*} \mathrm{SpG}\right) /\left(\mathrm{TOC}{ }^{*} \mathrm{SpG}\right) \\
& -5.4 \mathrm{E}-6^{*} \mathrm{TOC}^{\star} \mathrm{SpG}
\end{aligned}
$$

At the maximum TOC levels predicted by the above correlation, the peak concentration of combustible gases in the quenched off-gas will not exceed $60 \%$ of the lower flammable limit (LFL) during a $3 \mathrm{X}$ off-gas surge, provided that the indicated melter vapor space temperature and the total air supply to the melter are maintained above $650{ }^{\circ} \mathrm{C}$ and $850 \mathrm{lb} / \mathrm{hr}$, respectively, at the onset of a surge. At the reference DWPF melter feed rate of 0.9 GPM and a specific gravity of 1.48 , the maximum TOC level thus predicted is about $24,000 \mathrm{ppm}$ or $15.8 \mathrm{lb} / \mathrm{hr}$.

All the necessary calculations for this study were made using the 4-stage cold cap model and the melter off-gas dynamics model. A high degree of conservatism was included in the calculational bases and assumptions. As a result, the proposed correlations are believed to be conservative enough to be used for the melter offgas flammability control purposes.

\section{BACKGROUND}

One of the critical design and operating requirements for the DWPF melter off-gas system is to maintain the concentration of combustible components in the melter off-gas at the discharge of the Quencher below $60 \%$ of the LFL at off-gas flow rates 3 times normal. ${ }^{1}$ According to the National Fire Protection Assoriation (NFPA) Code $69,,^{2}$ this $60 \%$ LFL limit is applicable only when automatic instrumentation with safety interlocks is provided to control the concentration of combustible components. With no LFL analyzers in place, compliance with the 
Code 69 requires that all the operating variables that can contribute to the potential off-gas flammability be monitored, and necessary safety interlocks and operating procedures to control those variables be devised. 14

It was confirmed during the ninth Scale Glass Melter (SGM-9) run that the melter off-gas flammability during normal operation is largely determined by a set of conditions involving the following operating variables: ${ }^{3}$

- Carbon content in the feed.

- Melter vapor space temperature.

- Air flows for combustion and dilution.

One key operating variable not included in this list is the melter feed rate. Careful control of the feed rate is essential to maintaining a stable cold cap with enough venting holes, which is in turn essential to achieving a high melt rate consistently. Nevertheless, cold cap instability can still occur during feeding, and it is during these upset periods when abnormally high concentrations of combustible species can be vented into the off-gas system. The strategies currently used in DWPF to prevent potential off-gas flammability under these upset conditions are briefly discussed next.

\section{Carbon Content}

According to the reference DWPF Batch 1 sludge melter feed composition shown in Table 1,4 the sources for the combustible components in the feed include the formate and aromatic carbons present at 6,370 and $450 \mathrm{ppm}$, respectively, on an aqueous slurry mass basis. The aromatic carbon level of $450 \mathrm{ppm}$ represents about $1 \%$ of that entering the Salt Processing Cell (SPC), i.e., 99\% removal efficiency in the SPC and the Chemical Processing Cell (CPC) combined. This flowsheet value is based on the previous pilot-run data which showed that the aromatic carbon removal efficiency in the SPC alone was routinely over $95 \%$, and more than $90 \%$ of the remaining phenol was further removed in the CPC.5,6 Furthermore, DWPF currently has a technical safety requirement (TSR) on the maximum benzene and phenolboric acid (PBA) levels in the SPC aqueous product. So, the nominal TOC level in the melter feed is about $6,820 \mathrm{ppm}$, and can be increased mainly by increasing the formate carbon level.

The current DWPF melter feed redox criterion requires that the formate and nitrate concentrations in the feed must satisfy the following:

$$
\text { molar formate }(F)-\text { molar nitrate }(N) \leq R
$$


where $\mathrm{R}$ is a constant which takes a value of 0.5 at the nominal copper level, and can be greater than 1 at low copper levels. According to Eq. (1), the maximum formate carbon limit is determined by the absolute quantity of nitrate present in the feed as well as the value of $R$. It is then important to ensure that the maximum formate carbon limit set by the redox criterion does not push the TOC level high enough to lead to a potential for flammability in the melter off-gas system. At a fixed TOC level, this safety issue is determined by the operating characteristics of the melter off-gas system. Of all the operating variables, the feed rate is generally the most influential factor affecting off-gas flammability.

\section{Feed Rate}

The reference feed composition in Table 1 shows that the melter feed rate needs to be kept at $0.9 \mathrm{GPM}$ at $44.3 \mathrm{wt} \%$ total solids in order to maintain the design glass production rate of $228 \mathrm{lb} / \mathrm{hr}$. With all other operating variables fixed, increasing the feed rate would have more negative impact on off-gas flammability than increasing the TOC level alone, since the former not only increases the rate of the TOC being fed but lowers the melter vapor space temperature due to increased lid heat demand to vaporize and superheat the excess water. This adverse impact is likely to be more pronounced when surges occur more frequently. Currently, DWPF measures the TOC level in the feed, but has no upper limits on the feed rate.

\section{Melter Vapor Space Temperature}

The Basic Data Report requires that the melter vapor space or plenum temperature be kept at a temperature between 650 and $800^{\circ} \mathrm{C}$ in order to evaporate the feed water and to supplement the joule heat in melting the cold cap. ${ }^{1}$ DWPF currently has a low vapor space temperature interlock at $650^{\circ} \mathrm{C}$, and this low-temperature interlock is set based on the temperature readings measured in the vapor space thermowells. However, due to thermal radiation effects on the thermowells, the actual gas temperature at the indicated vapor space temperature of $650^{\circ} \mathrm{C}$ is estimated to be only about $470{ }^{\circ} \mathrm{C}$ using the available correlation. ${ }^{7}$

In the calculations of combustion kinetics, it is the actual gas temperature that counts, and the apparent rate constants for the overall $\mathrm{CO}$ and $\mathrm{H}_{2}$ oxidation in the melter vapor space were shown earlier to vary with the gas temperature according to the well-known Arrhenius form. ${ }^{8}$ During typical off-gas surges lasting only several seconds, the actual cooldown of the vapor space will not be reflected correctly on the indicated temperatures due to thermal inertia of the thermowells. Thus, the temperature correlation mentioned above cannot be used to predict the gas temperature variations during surges for transient combustion calculations. 


\section{TABLE 1. Reference DWPF Batch 1 Sludge Melter Feed Composition}

\begin{tabular}{|c|c|}
\hline $\begin{array}{l}\text { Formate/Nitrate } \\
\text { Species }\end{array}$ & $\mathrm{lb} / \mathrm{hr}$ \\
\hline $\mathrm{Ca}(\mathrm{COOH}) 2$ & $3.902 E-02$ \\
\hline $\mathrm{Ca}(\mathrm{NO} 3) 2$ & $2.607 E+\infty$ \\
\hline $\mathrm{Co}(\mathrm{COOH}) 2$ & $2.045 E-04$ \\
\hline $\mathrm{CO}(\mathrm{NO} 3)_{2}$ & $0.000 E+00$ \\
\hline $\mathrm{CsCOOH}$ & 2.135E-01 \\
\hline CsNO3 & $5.308 E-04$ \\
\hline $\mathrm{Cu}(\mathrm{COOH}) 2$ & $1.548 E+00$ \\
\hline $\mathrm{Cu}(\mathrm{NO} 3) 2$ & $0.000 \mathrm{E}+00$ \\
\hline $\mathrm{KCOOH}$ & $9.477 E+00$ \\
\hline KNO3 & 3.146E-02 \\
\hline $\mathrm{Mg}(\mathrm{COOH}) 2$ & $3.249 E+00$ \\
\hline $\mathrm{Mg}(\mathrm{NO}) 2$ & $0.000 E+00$ \\
\hline $\mathrm{Mn}(\mathrm{COOH}) 2$ & $2.349 E+00$ \\
\hline $\mathrm{Mn}(\mathrm{NO} 3) 2$ & $0.000 E+00$ \\
\hline $\mathrm{NH} 4 \mathrm{COOH}$ & $0.000 E+00$ \\
\hline NH4NO3 & $2.438 E-03$ \\
\hline $\mathrm{NaCOOH}$ & $6.296 \mathrm{E}+00$ \\
\hline NaNO3 & $1.584 \mathrm{E}+01$ \\
\hline $\mathrm{Ni}(\mathrm{COOH}) 2$ & 4.172E-02 \\
\hline $\mathrm{Ni}(\mathrm{NO} 3)_{2}$ & $0.000 E+00$ \\
\hline $\mathrm{Pb}(\mathrm{NO} 3) 2$ & 4.217E-05 \\
\hline $\mathrm{Pd}(\mathrm{NO} 3)_{2}$ & $0.000 \mathrm{E}+\infty 0$ \\
\hline $\mathrm{Sr}(\mathrm{COOH}) 2$ & $1.789 E-03$ \\
\hline $\mathrm{Sr}(\mathrm{NO} 3) 2$ & $2.798 \mathrm{E}-02$ \\
\hline $\mathrm{UO} 2(\mathrm{COOH}) 2$ & $7.923 E-08$ \\
\hline $\mathrm{UO} 2(\mathrm{NO} 3)_{2}$ & 9.601E-05 \\
\hline $\mathrm{Y}(\mathrm{COOH}) 3$ & 7.190E-04 \\
\hline$Y(N O 3) 3$ & $1.004 \mathrm{E}-02$ \\
\hline $\mathrm{Zn}(\mathrm{COOH}) 2$ & $6.100 \mathrm{E}-02$ \\
\hline $\mathrm{Zn}(\mathrm{NO}) 2$ & $0.000 E+00$ \\
\hline Total_1 = & 4.180E+01 \\
\hline $\mathrm{COOH}-\mathrm{NO} 3, \mathrm{M}$ & 2.196E-01 \\
\hline tot formate salts & $2.328 E+01$ \\
\hline total nitrate salts* & $1.852 E+01$ \\
\hline
\end{tabular}

\begin{tabular}{|c|c|}
\hline $\begin{array}{l}\text { Organic } \\
\text { Species }\end{array}$ & $\mathrm{lb} / \mathrm{hr}$ \\
\hline$(\mathrm{C} 6 \mathrm{H} 5)_{2}$ & $0.000 E+00$ \\
\hline$(\mathrm{C} 6 \mathrm{H} 5)_{2} \mathrm{C} 6 \mathrm{H} 4$ & $6.362 E-02$ \\
\hline (C6H5)2NH & $0.000 E+00$ \\
\hline $\mathrm{C} 6 \mathrm{H} 5 \mathrm{~B}(\mathrm{OH}) 2$ & $0.000 E+00$ \\
\hline $\mathrm{C} 6 \mathrm{H} 5 \mathrm{C} 6 \mathrm{H} 4 \mathrm{OH}$ & 4.791E-02 \\
\hline $\mathrm{C} 6 \mathrm{H} 5 \mathrm{NH} 2$ & $1.612 \mathrm{E}-04$ \\
\hline C6H5NHCHO & $1.786 \mathrm{E}-01$ \\
\hline $\mathrm{C} 6 \mathrm{H} 5 \mathrm{NO}$ & $2.919 \mathrm{E}-03$ \\
\hline C6H5NO2 & $5.923 \mathrm{E}-03$ \\
\hline $\mathrm{C} 6 \mathrm{H} 5 \mathrm{OH}$ & 4.956E-02 \\
\hline $\mathrm{C} 6 \mathrm{H} 6$ & $0.000 E+00$ \\
\hline$(\mathrm{CH} 3)_{2} \mathrm{CHOH}$ & $0.000 E+00$ \\
\hline $\mathrm{CH} 3 \mathrm{OH}$ & $0.000 E+00$ \\
\hline Total_2 = & $3.487 E-01$ \\
\hline $\begin{array}{l}\text { stoichiometric } 02 \\
\text { to burn } 100 \% \text { org }\end{array}$ & \\
\hline & $4.544 E+00$ \\
\hline Total Feed & \\
\hline$(\mathrm{lb} / \mathrm{hr})=$ & 598.9745 \\
\hline$(G P M)=$ & 0.9005 \\
\hline$w+\%$ total solids = & 44.2881 \\
\hline$w+\%$ insolubles = & 35.8538 \\
\hline specific gravity = & 1.3312 \\
\hline Carbon Feeds & $\mathrm{lb} / \mathrm{hr}$ \\
\hline Formate $=$ & 3.8194 \\
\hline Aromatic $=$ & 0.2681 \\
\hline Misc $=$ & 0.0321 \\
\hline Total Carbon = & 4.1195 \\
\hline $\begin{array}{l}\text { glass prod exc. } \\
\text { entrainm't (lb/hr)= }\end{array}$ & 228 \\
\hline
\end{tabular}

\begin{tabular}{|c|c|c|}
\hline \multirow{2}{*}{$\begin{array}{l}\text { Other Inorgani } \\
\text { Species }\end{array}$} & \multicolumn{2}{|c|}{ Other Inorganic } \\
\hline & $\mathrm{lb} / \mathrm{hr}$ Species & $\mathrm{lb} / \mathrm{hr}$ \\
\hline $\mathrm{Ag}$ & 1.245E-02 $\mathrm{PbCO} 3$ & $2.800 \mathrm{E}-04$ \\
\hline $\mathrm{Al} 2 \mathrm{O} 3$ & 1.028E+01 PbSO4 & $9.870 E-02$ \\
\hline $\mathrm{B} 2 \mathrm{O} 3$ & $1.296 E+01$ PUO2 & 8.545E-03 \\
\hline $\mathrm{Ba}(\mathrm{OH})_{2}$ & $0.000 E+00 \mathrm{Rh}$ & 1.751E-03 \\
\hline BasO4 & 2.336E-01 Ru & $8.130 E-03$ \\
\hline $\mathrm{Ca}(\mathrm{OH}) 2$ & $0.000 \mathrm{E}+00 \mathrm{SiO} 2$ & $1.260 E+02$ \\
\hline $\mathrm{Ca}(\mathrm{PO} 4) 2$ & $2.407 \mathrm{E}+00 \mathrm{TCO} 2$ & $2.888 \mathrm{E}-03$ \\
\hline $\mathrm{CaC}_{2} \mathrm{O}_{4}$ & 6.364E-02 ThO2 & $1.343 E-01$ \\
\hline $\mathrm{CaF} 2$ & 1.646E-02 TiO2 & $7.645 E-01$ \\
\hline $\mathrm{CaO}$ & 3.131E-03 U308 & $2.328 E+00$ \\
\hline $\mathrm{CaSO}_{4}$ & 5.472E-02 Zeolite & $2.187 E-03$ \\
\hline $\mathrm{Cr} 2 \mathrm{O} 3$ & $1.757 \mathrm{E}-01 \mathrm{ZnO}$ & 7.215E-02 \\
\hline $\mathrm{Cs} 2 \mathrm{O}$ & 2.480E-04 hyd $\mathrm{H} 2 \mathrm{O}$ & $6.326 E+00$ \\
\hline CuO & 2.347E-02 $\mathrm{H} 2 \mathrm{O}$ & $3.337 E+02$ \\
\hline $\mathrm{Fe} 2 \mathrm{O} 3$ & $2.373 E+01$ & \\
\hline $\mathrm{H} 2 \mathrm{C} 2 \mathrm{O} 4$ & 7.563E-02 Total_3 = & $5.568 E+02$ \\
\hline $\mathrm{H} 3 \mathrm{BO} 3$ & $8.076 E+00$ & \\
\hline $\mathrm{Hg}$ & 2.412E-01 & \\
\hline $\mathrm{K} 2 \mathrm{O}$ & $1.125 E-01$ & \\
\hline $\mathrm{Li2O}$ & $1.134 E+01$ & \\
\hline $\mathrm{MgO}$ & $3.526 E+00$ & \\
\hline $\mathrm{MnO} 2$ & $2.026 E+00$ & \\
\hline $\mathrm{MoO} 2$ & 1.690E-03 & \\
\hline $\mathrm{NH} 4 \mathrm{OH}$ & $8.660 \mathrm{E}-02$ & \\
\hline $\mathrm{Na2O}$ & $1.114 E+01$ & \\
\hline $\mathrm{Na2SO} 4$ & $4.246 \mathrm{E}-01$ & \\
\hline $\mathrm{Na} 3 \mathrm{PO} 4$ & $1.020 E-02$ & \\
\hline $\mathrm{NaCl}$ & $3.386 \mathrm{E}-02$ & \\
\hline $\mathrm{NaF}$ & $3.348 E-02$ & \\
\hline $\mathrm{NiO}$ & 2.937E-01 & \\
\hline
\end{tabular}

- Total formate \& nitrate salts includes cations. 


\section{Combustion / Dilution Air}

Much of the air purge required for the combustion of off-gas combustibles is supplied through the backup film cooler (BUFC). In an earlier study, 9 the minimum air flow rate to the BUFC was determined to be $220 \mathrm{lb} / \mathrm{hr}$, and DWPF currently has a low-flow interlock for the BUFC air FIC-3221B at $250 \mathrm{lb} / \mathrm{hr}$. Additional combustion air is supplied through the seal pot and the TV cameras in the form of air purges, totaling $80 \mathrm{lb} / \mathrm{hr}$. Thus, the total air purge to the melter vapor space is in $50 \%$ excess of the stoichiometric requirement at a conservatively low aromatic carbon removal rate of $85 \%$ and the nominal formate carbon level. 9

Under normal operating conditions, the combustion in the melter plenum will be nearly complete, ${ }^{10}$ and the combustibles concentration in the off-gas exiting the melter is significantly low, thus requiring little dilution air downstream. However, in the event of a large off-gas surge, the gas temperature in the melter vapor space can drop significantly below its normal operating value, resulting in a marked reduction in combustion efficiency. This reduced combustion efficiency coupled with increased combustibles concentration during off-gas surges could push the combustibles concentration beyond the LFL. So, the dilution air flow rate should be set so as to maintain the combustibles concentration downstream below $60 \%$ of the LFL under these abnormal conditions.

In DWPF, this dilution air is supplied through the primary film cooler (PFC). The air flow rate to the PFC is controlled by the FIC-3221A which receives signals from the transmitter which reads the total melter air flow, including the air flows to the BUFC, seal pot and TV cameras. The air purge rates to the seal pot and TV cameras are limited to 20 and $120 \mathrm{lb} / \mathrm{hr}$, respectively. So, at the current low-flow interlock values of 850 and $250 \mathrm{lb} / \mathrm{hr}$ for the FIC-3221A and FIC-3221B, respectively, the total dilution air flow to the PFC is $460 \mathrm{lb} / \mathrm{hr}$. Note that $50 \%$ of the $120 \mathrm{lb} / \mathrm{hr}$ air purge to the TV cameras is vented out to the cell. In addition, the dilution air flow to the PFC also cools the off-gas, and helps transport off-gas entrainments to the quencher. It should be noted that the melter pressure control air flow, which is set at $500 \mathrm{lb} / \mathrm{hr}$ during normal operation, and any air inleakages to the melter off-gas system are not considered as dilution sources.

\section{Off-Gas Surges}

In both off-gas system dynamics and flammability studies, upset conditions are typically simulated by creating a sudden surge in the vapor flow rate. Off-gas surges are mainly attributed to the inherent instability of the cold cap which is known to be related to many design and operating characteristics, including the size of the melter, vapor space temperature and feed composition. As a result, it is practically impossible to predict both the frequency and characteristics of surges 
such as peak intensity and duration from a given set of operating conditions. Instead, representative surge patterns have been constructed from the results of pilot melter runs, ${ }^{11,15,16}$ and subsequently used in the design basis calculations.

As stated earlier, the DWPF Basic Data Report (BDR) specifies the design basis abnormal melter off-gas flow rate of 3 times normal (3X) for the flammability control purposes, ${ }^{1}$ and it is implicitly assumed that the $3 \mathrm{X}$ off-gas flow continues indefinitely. Realistically, however, large surges cannot last for an extended period of time. Based on an earlier study, ${ }^{11}$ the total duration of the design basis $7 \mathrm{X}$ surge for the melter pressure protection was set at 8 minutes, which was subsequently used in all dynamic simulation studies. However, recent DWPF cold run data showed that the peak surge intensity may be greater than $7 \mathrm{X}$, but the surge duration is generally on the order of only several seconds.

\section{Earlier Work on Maximum TOC}

SRTC recommended earlier that the TOC level in the DWPF melter feed be less than $24,000 \mathrm{ppm}$ on an aqueous slurry basis. ${ }^{8}$ The composition of the reference melter feed used in the analysis was identical to that shown in Table 1. In order to increase the TOC level above nominal $6,820 \mathrm{ppm}$, the formate carbon level was first increased from nominal $6,370 \mathrm{ppm}$ to a maximum of $8,900 \mathrm{ppm}$ by imposing the feed redox constraint of $\mathrm{F}-\mathrm{N}=0.5$ at the baseline nitrate level of 0.485 molar. Then, the maximum TOC limit of $24,000 \mathrm{ppm}$ was determined by increasing the aromatic carbon level from nominal $450 \mathrm{ppm}$ to $15,100 \mathrm{ppm}$ at which point the calculated peak concentration of combustible components in the quenched off-gas was at $60 \%$ of the LFL during a $3 \mathrm{X}$ off-gas surge. In doing so, the overall aromatic carbon removal efficiency across the SPC and CPC was reduced to only $76 \%$, which is considerably lower than the experimentally observed values. ${ }^{5,6}$ As described next, this approach to increasing the TOC level was revised significantly during the present study to better reflect the actual data.

\section{BASES AND ASSUMPTIONS}

One of the primary objectives of this study was to extend the scope of the earlier TOC work by varying the feed rate, i.e., to determine the maximum TOC limit as a function of feed rate. Some of the calculational bases assumed in the earlier work were also modified to better reflect the current conditions in DWPF. As a result, the overall approach taken to determine the maximum TOC limit was changed from one of finding the highest aromatic carbon level at a given formate carbon level determined by a fixed redox ratio of 0.5 to finding the highest formate carbon level at a fixed aromatic carbon level set by assuming a conservative aromatic carbon removal efficiency. In doing so, the melter feed 
redox constraint shown in Eq. (1) was overridden. In summary, the bases and assumptions used in this study include:

- The composition of the reference DWPF melter feed is represented by that given in Table 1, which was calculated using the Tanks $42 / 51$ blend sludge and the average salt feeds, and has the following characteristics: 4

- total solids $=44.3 \mathrm{wt} \%$

- nitrates $(\mathrm{N})=0.485$ molar

- formates $(F)=0.705$ molar

- formate carbon $=6,370 \mathrm{ppm}$ (aqueous slurry basis)

- aromatic carbon $=450 \mathrm{ppm}$ (aqueous slurry basis)

- The combined efficiency of aromatic carbon removal in the SPC and CPC is set at $95 \%$, i.e., $95 \%$ of aromatic carbons entering the SPC remains in the melter feed. This increases the aromatic carbon level from 450 to $3,100 \mathrm{ppm}$ at $44.3 \mathrm{wt} \%$ total solids.

- At a given feed rate, the formate carbon level is then increased from nominal $6,370 \mathrm{ppm}$ to a maximum value where the peak concentration of combustible components in the quenched off-gas reaches $60 \%$ of the LFL during a $3 \mathrm{X}$ off-gas surge.

- The melter vapor space temperature measured in the thermowells is at the low-temperature interlock of $650^{\circ} \mathrm{C}$ at the onset of a $3 \mathrm{X}$ surge. (At this indicated temperature, the actual plenum gas temperature is about $470^{\circ} \mathrm{C}$.)

- The air purge rate to the BUFC is kept at the low-flow interlock of $220 \mathrm{lb} / \mathrm{hr}$ plus $30 \mathrm{lb} / \mathrm{hr}$ line purge.

- The total melter air flow rate to the FIC-3221A is kept at the current low-flow interlock of $850 \mathrm{lb} / \mathrm{hr}$.

- The $3 \mathrm{X}$ off-gas surge is assumed to proceed as follows: At time zero, the flow rates of both condensable and noncondensable gases generated from the feed are increased from $1 \mathrm{X}$ to $3 \mathrm{X}$ normal instantly, then decreased linearly to $1.5 \mathrm{X}$ normal during the first 1 minute, and further decreased linearly to $1 \mathrm{X}$ normal during the next 7 minutes. 11 


\section{OVERVIEW OF MODELS}

A description of the two models used in this study was given earlier.7,8,12,13 The 4stage cold cap model was first run to calculate the compositions of glass and calcine gases from a given feed composition.7,8 The composition of calcine gases was then used in the melter off-gas dynamics model to predict the simultaneous transient responses of the off-gas system parameters during a $3 \mathrm{X}$ off-gas surge, including pressures, temperatures and concentrations. ${ }^{8,12,13}$

Briefly, the 4-stage cold cap model approximates the entire melting process as a continuous, multistage process consisting of a series of simple, recognizable physical and chemical events that are similar to those observed by differential scanning calorimetry and X-ray diffraction experiments. In principle, this model assumes that all the chemical events taking place in the cold cap are at thermodynamic equilibrium, thereby ignoring the effects of chemical kinetics and transport resistances. Once equilibrium compositions are determined for the gas and liquid phases in each stage, the gas phase is fed to next stage above, and the liquid phase is fed to the next stage below, thus establishing countercurrent flows between stages.

The 4-stage cold cap model was validated earlier against the data obtained with the formic acid flowsheet feeds, ${ }^{7}$ but is yet to be validated for the nitric acid flowsheet feeds. Therefore, as described earlier, ${ }^{8}$ the oxidizing effects of nitrate salts were ignored, and the calculated equilibrium off-gas compositions were adjusted to match the conservative formic acid flowsheet compositions.

The melter off-gas dynamics model has been used extensively in DWPF to study the dynamic responses of the entire melter off-gas system under many transient conditions such as off-gas surges, switchover and switchback between the primary and backup off-gas systems, initial startup and idling, feed tube flushing, etc. 12,13 All the controller hardware and software logic currently used in the DWPF melter off-gas system are simulated by this model. The combustion in the melter plenum is modeled using the apparent first-order rate parameters derived from the SGM-9 data. ${ }^{8}$ When the feed composition is changed, this model requires a new input from the 4-stage cold cap model in order to predict off-gas flammability correctly.

\section{RESULTS AND DISCUSSION}

The results of the $3 X$ surge dynamic simulation are shown in Figures A-1 to A-9 in Appendix in the order of increasing feed rates from 0.7 to $1.5 \mathrm{GPM}$ at $0.1 \mathrm{GPM}$ increments. As the feed rate is more than doubled from 0.7 to $1.5 \mathrm{GPM}$, the peak melter pressure during the $3 \mathrm{X}$ surge is shown to increase by only 1 inch $\mathrm{H}_{2} \mathrm{O}$ from -4.3 to -3.4 in $\mathrm{H}_{2} \mathrm{O}$. As expected, the decrease in melter plenum gas temperature due to surges is the largest at $1.5 \mathrm{GPM}$. 
Table 2 summarizes the calculated maximum TOC limits at different feed rates. It is clearly shown that as the feed rate is increased, the maximum TOC limit that can be tolerated by the melter without exceeding $60 \%$ of the LFL decreases. At 0.7 GPM, feeds containing up to $35,400 \mathrm{ppm}$ TOC can be fed, but the maximum TOC limit drops to only $10,200 \mathrm{ppm}$ at $1.5 \mathrm{GPM}$. It is also noted in Table 2 that the estimated specific gravity of the feed increases as the TOC level is increased. This is because only the formate level was increased from that of the reference feed in Table 1 to a maximum value at each feed rate, while holding the contents of insoluble solids, other salts and water constant, thereby effectively increasing the total solids content of a batch.

Figure 1 is a plot of wt\% total solids vs. specific gravity for three DWPF melter feed slurry samples (MFT-5,6,7), and the following correlation for the specific gravity was derived and subsequently used in this study:

$$
S p G=0.3017+0.023245^{\star} T S
$$

where TS is the total solids content of the slurry feed in wt\% between 43 and 54 .

TABLE 2. Results of 3X Surge Dynamic Simulation Runs

\begin{tabular}{ccccccc}
\hline Feed Rate & $\begin{array}{c}\text { Estimated } \\
\text { Specific } \\
\text { Gravity }\end{array}$ & $\begin{array}{c}\text { Formate } \\
\text { Carbon } \\
(\mathrm{ppm})\end{array}$ & $\begin{array}{c}\text { Aromatic } \\
\text { Carbon } \\
(\mathrm{ppm})\end{array}$ & \multicolumn{2}{c}{ Maximum TOC } & $\begin{array}{c}\text { Glass } \\
\text { Production } \\
(\mathrm{lb} / \mathrm{hr})\end{array}$ \\
\hline 0.7 & 1.5525 & 32,800 & 2,600 & 35,400 & 19.263 & 219 \\
0.8 & 1.5032 & 26,800 & 2,700 & 29,500 & 17.763 & 239 \\
0.9 & 1.4614 & 21,700 & 2,800 & 24,500 & 16.136 & 259 \\
1.0 & 1.4322 & 18,100 & 2,900 & 21,000 & 15.060 & 281 \\
1.1 & 1.4071 & 15,040 & 2,960 & 18,000 & 13.951 & 301 \\
1.2 & 1.3846 & 12,280 & 3,020 & 15,300 & 12.729 & 322 \\
1.3 & 1.3678 & 10,240 & 3,060 & 13,300 & 11.842 & 344 \\
1.4 & 1.3545 & 8,600 & 3,100 & 11,700 & 11.109 & 365 \\
1.5 & 1.3419 & 7,080 & 3,120 & 10,200 & 10.280 & 387 \\
\hline
\end{tabular}




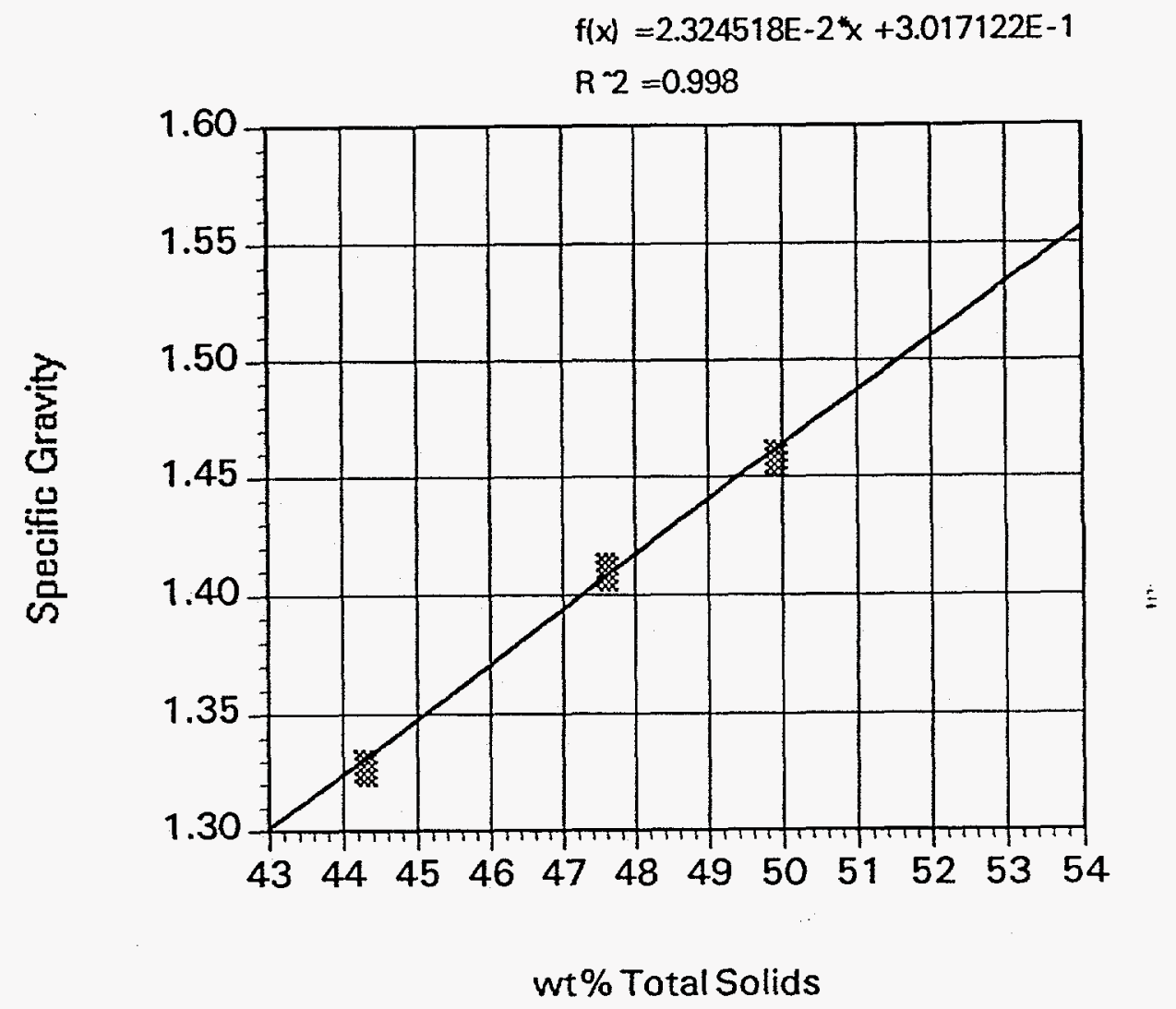

\section{FIGURE 1. wt\% Total Solids vs. Specific Gravity for MFT Samples}

At the total solids content of $44.2881 \mathrm{wt} \%$, Eq. (2) predicts the specific gravity of 1.3312, which is identical to that given in Table 1 for the reference feed. Although Eq. (2) shows the specific gravity as a function of total solids content only, it is recommended that the use of Eq. (2) be limited to slurry feeds containing about 30 to $40 \mathrm{wt} \%$ insoluble solids. The impact of varying insoluble solids contents is discussed later.

The calculated maximum TOC limits in Table 2 are plotted next in Figure 2 against the product of feed rate and specific gravity, and the following correlation was derived:

$$
\max T O C(p p m)=45,180 * F R * S p G-108,200 L n(F R * S p G)-4,860
$$

where FR is the feed rate in GPM, and SpG is the specific gravity of the feed. 


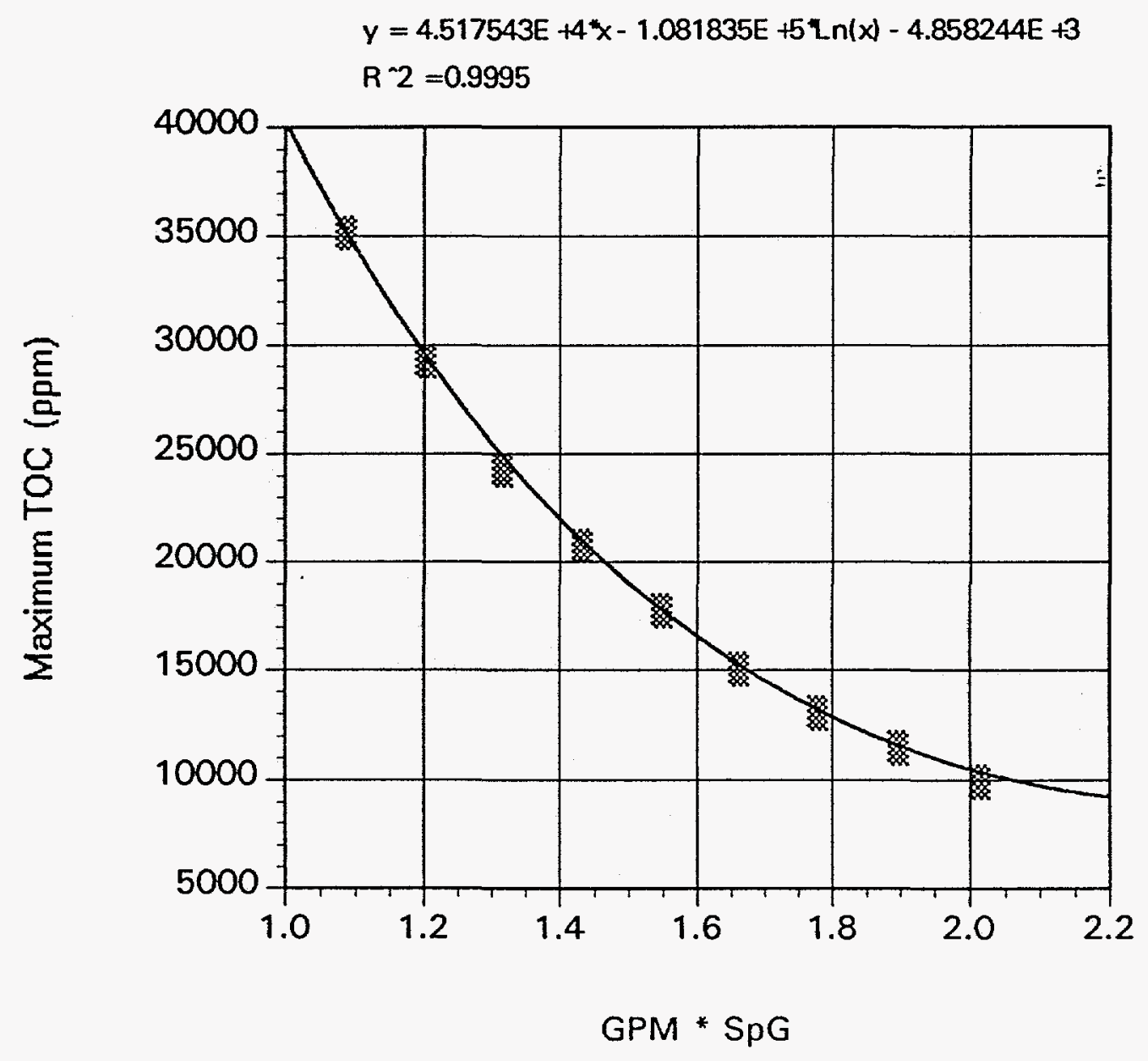

FIGURE 2. Maximum Total Organic Carbon vs. Feed Rate*Specific Gravity 
In order to test the applicability of Eq. (3) to operating conditions other than those shown in Table 2, a case was next considered where one plans to increase the feed rate to $1.2 \mathrm{GPM}$ and, using Eq. (3), has determined a maximum TOC level of $13,200 \mathrm{ppm}$ at the specific gravity of 1.48 . Figure 3 is the result of the dynamic simulation run under these conditions, which indeed predicts that the peak concentration of combustibles will not exceed $60 \%$ of the LFL during a $3 X$ surge.

The estimated specific gravities and the feed rates in Table 2 are plotted next in Figure 4 against the TOC level. Once the TOC level and the specific gravity are measured, Figure 4 can be used to predict the maximum allowable feed rate. For example, when the measured TOC level is $28,000 \mathrm{ppm}$, Figure 4 shows that the feed rate can be as high as $0.83 \mathrm{GPM}$, as long as the measured specific gravity is less than 1.49 .

These maximum feed rates are plotted next in Figure 5 as a function of the product of TOC in ppm and specific gravity, and the following correlation was derived:

$$
\begin{aligned}
\max \text { feed rate }(\mathrm{GPM})= & 0.756+1,185.5 \mathrm{Ln}\left(\mathrm{TOC}{ }^{*} \mathrm{SpG}\right) /\left(\mathrm{TOC}{ }^{*} \mathrm{SpG}\right) \\
& -5.4 \mathrm{E}-6^{*} \mathrm{TOC}{ }^{\star} \mathrm{SpG}
\end{aligned}
$$

In order to validate the applicability of Eq. (4) to operating conditions other than those shown in Table 2, another test case was considered where one has experimental measurements on the TOC and specific gravity at $21,000 \mathrm{ppm}$ and 1.48 , respectively, and has determined a maximum feed rate of 0.983 GPM using Eq. (3). Figure 6 is the result of the dynamic simulation under these conditions, which indeed predicts that the peak concentration of combustibles will not exceed $60 \%$ of the LFL during a $3 X$ surge.

The maximum TOC feed rates in Table 2 are plotted next in Figure 7 against the ratio of TOC in ppm to specific gravity, and the following correlation was derived:

$$
\begin{aligned}
\max \text { TOC feed rate }(\mathrm{lb} / \mathrm{hr})= & 9.55+4.78 \mathrm{E}-4^{*}(\mathrm{TOC} / \mathrm{SpG}) \\
& -2.5 \mathrm{E}+3^{*} \mathrm{Ln}(\mathrm{TOC} / \mathrm{SpG}) /(\mathrm{TOC} / \mathrm{SpG})
\end{aligned}
$$

It should be noted that it is the feed rate of TOC, not the TOC concentration or the slurry feed rate alone, that directly affects the off-gas flammability calculations. Eq. (5) can be used to convert the measured TOC concentration into the maximum allowable TOC feed rate once the specific gravity of the feed is known. This shows the importance of the specific gravity in this TOC study. Specific gravities are also important in dynamic simulations, since they generally relate the slurry feed rate to the relative ratio of condensable to noncondensable components in the off-gas flow. 

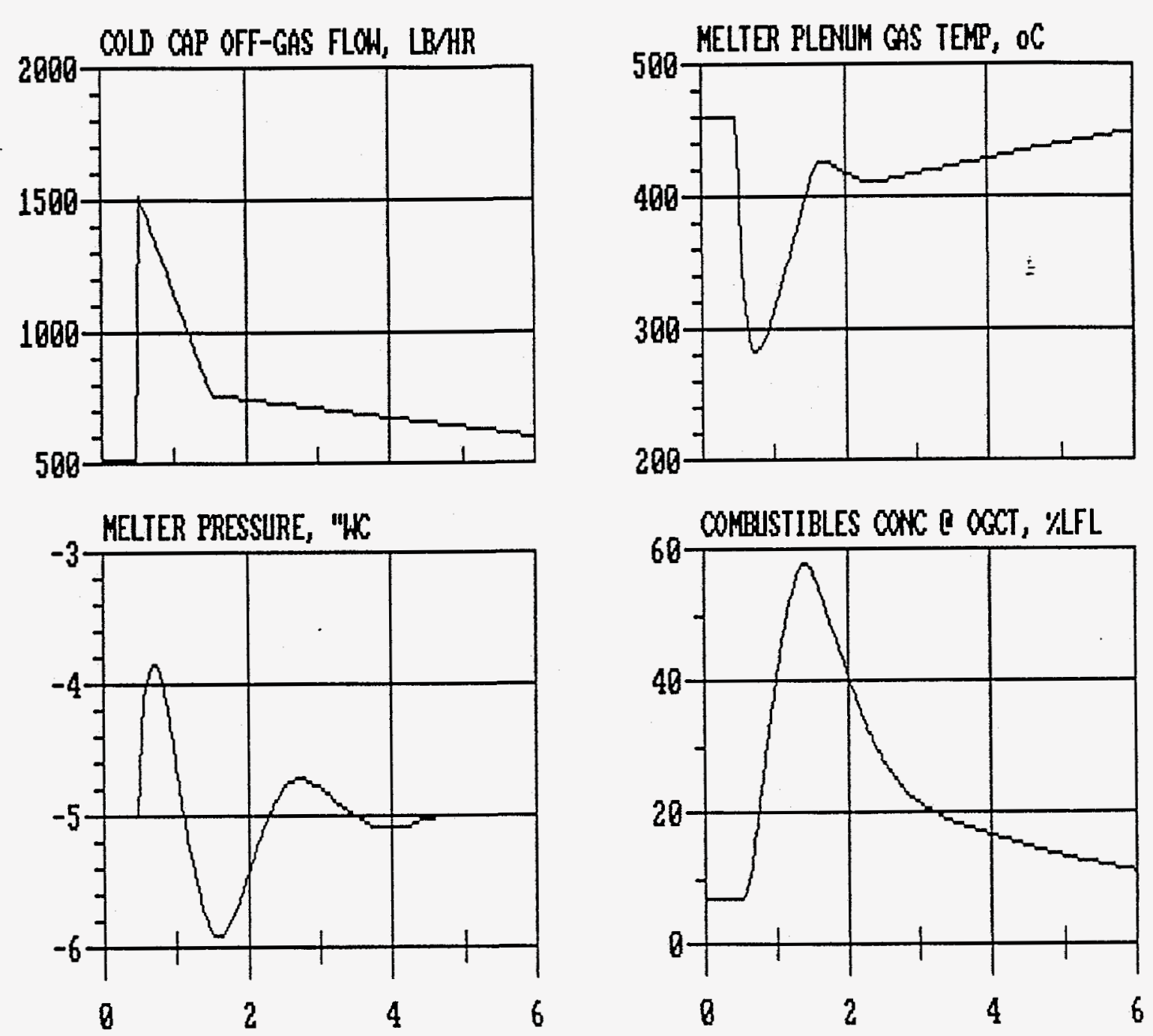

TIME IN MINUTES

FIGURE 3. 3X Surge Simulation Result $(13,200 \mathrm{ppm}$ TOC, 1.2 GPM) 


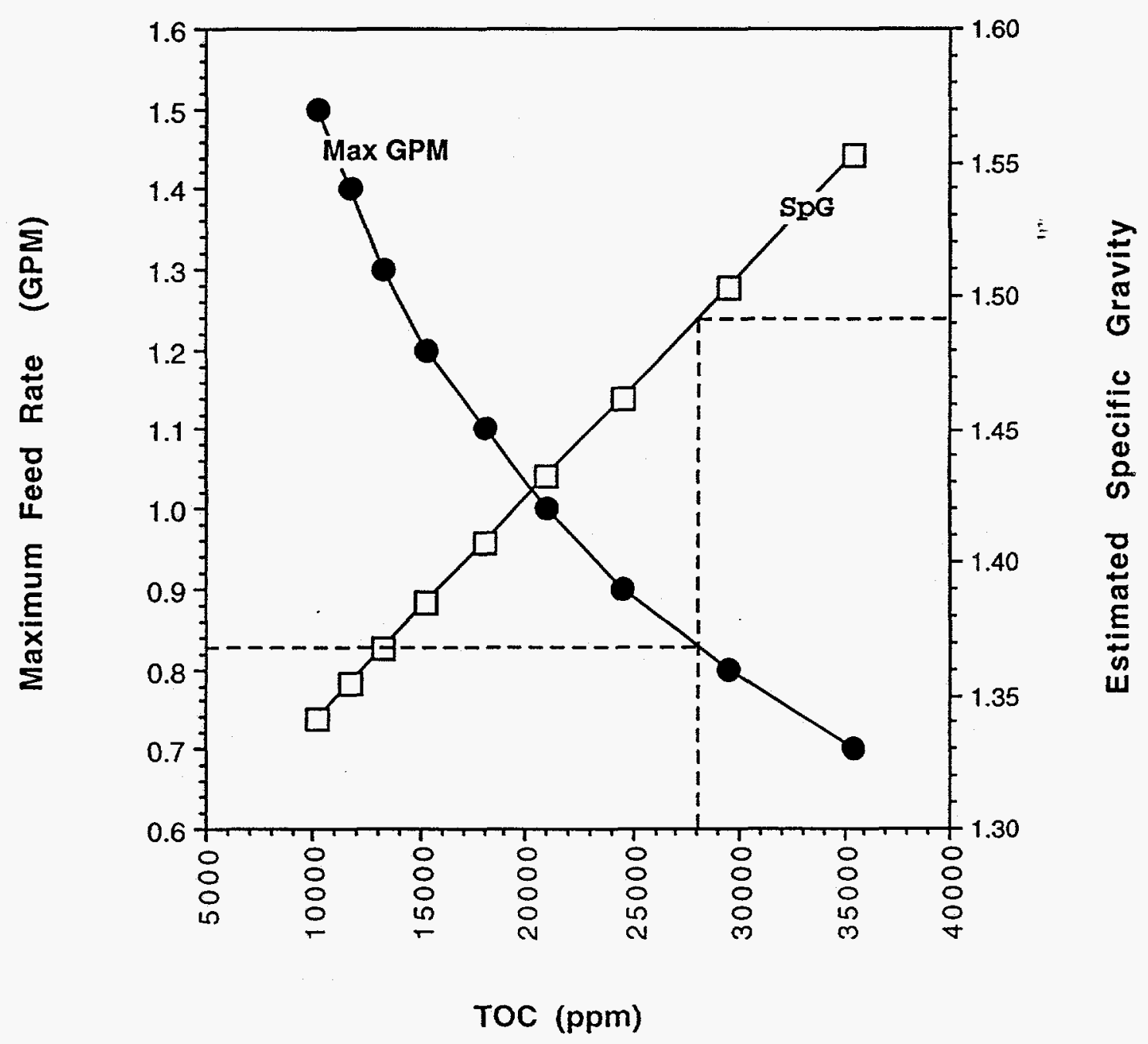

FIGURE 4. Maximum Feed Rate \& Estimated Specific Gravity vs. TOC 


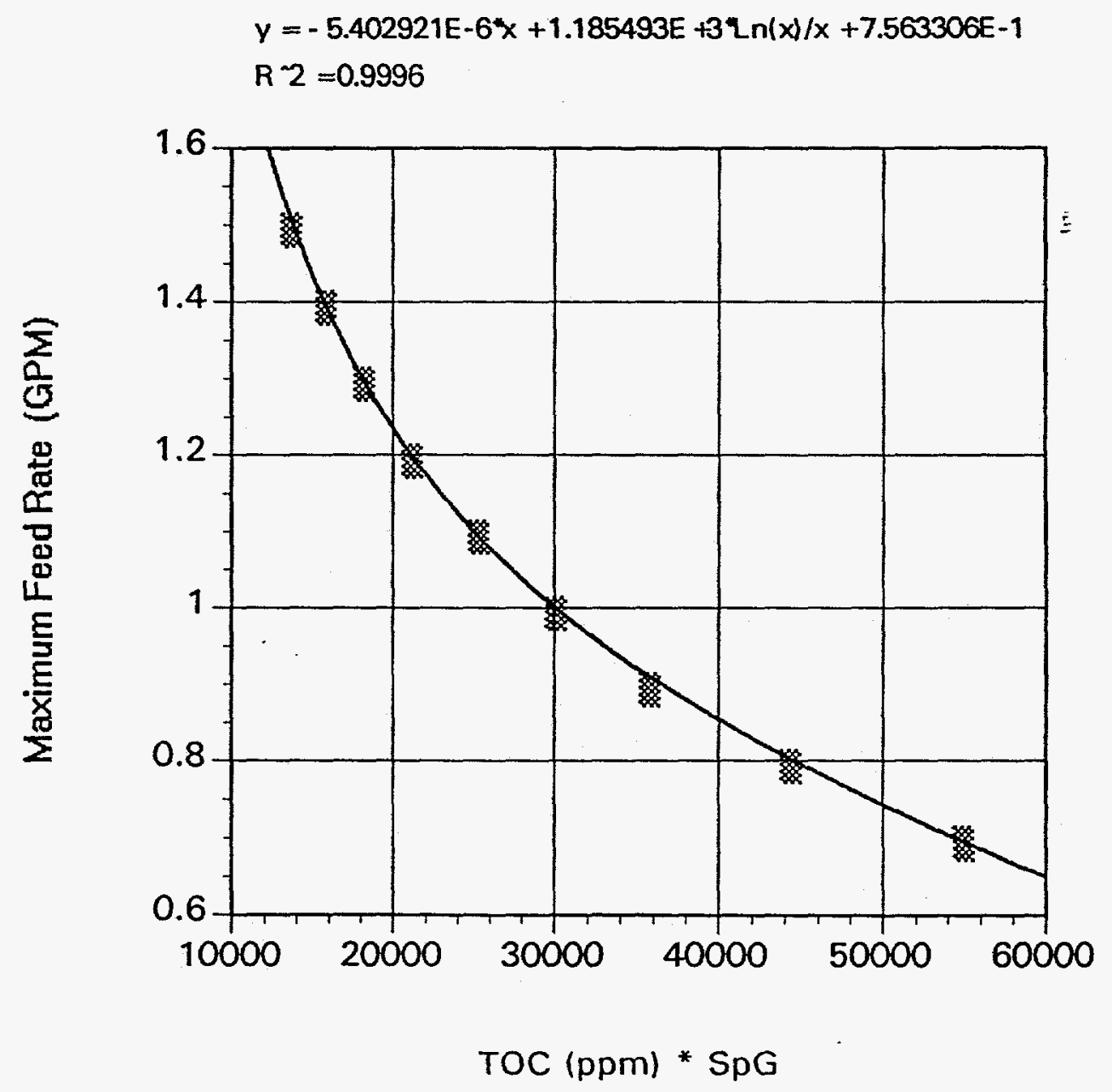

FIGURE 5. Maximum Feed Rate vs. TOC * Specific Gravity 

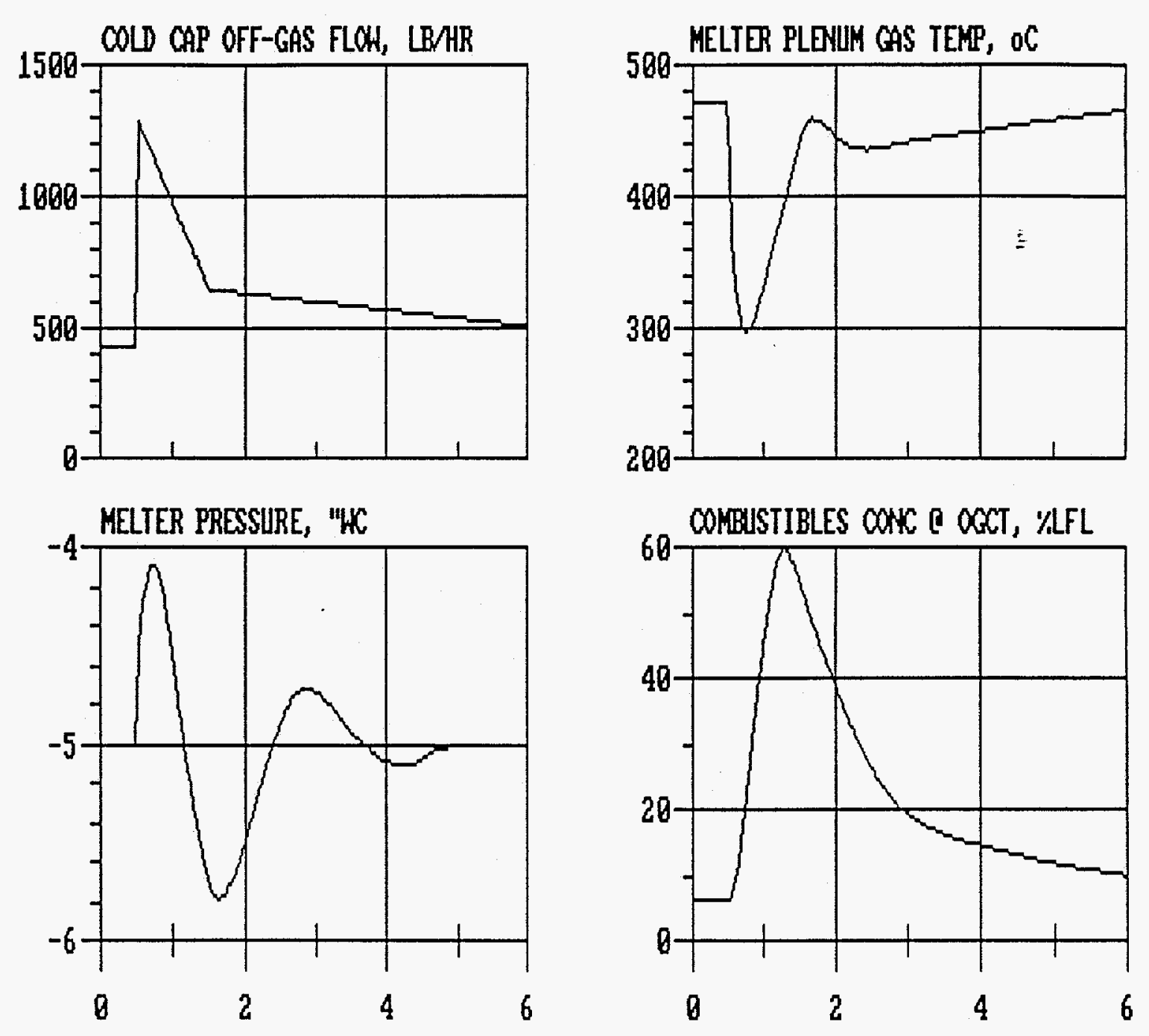

TIME IN MINUTES

FIGURE 6. 3X Surge Simulation Result $(21,000 \mathrm{ppm}$ TOC, 0.983 GPM) 


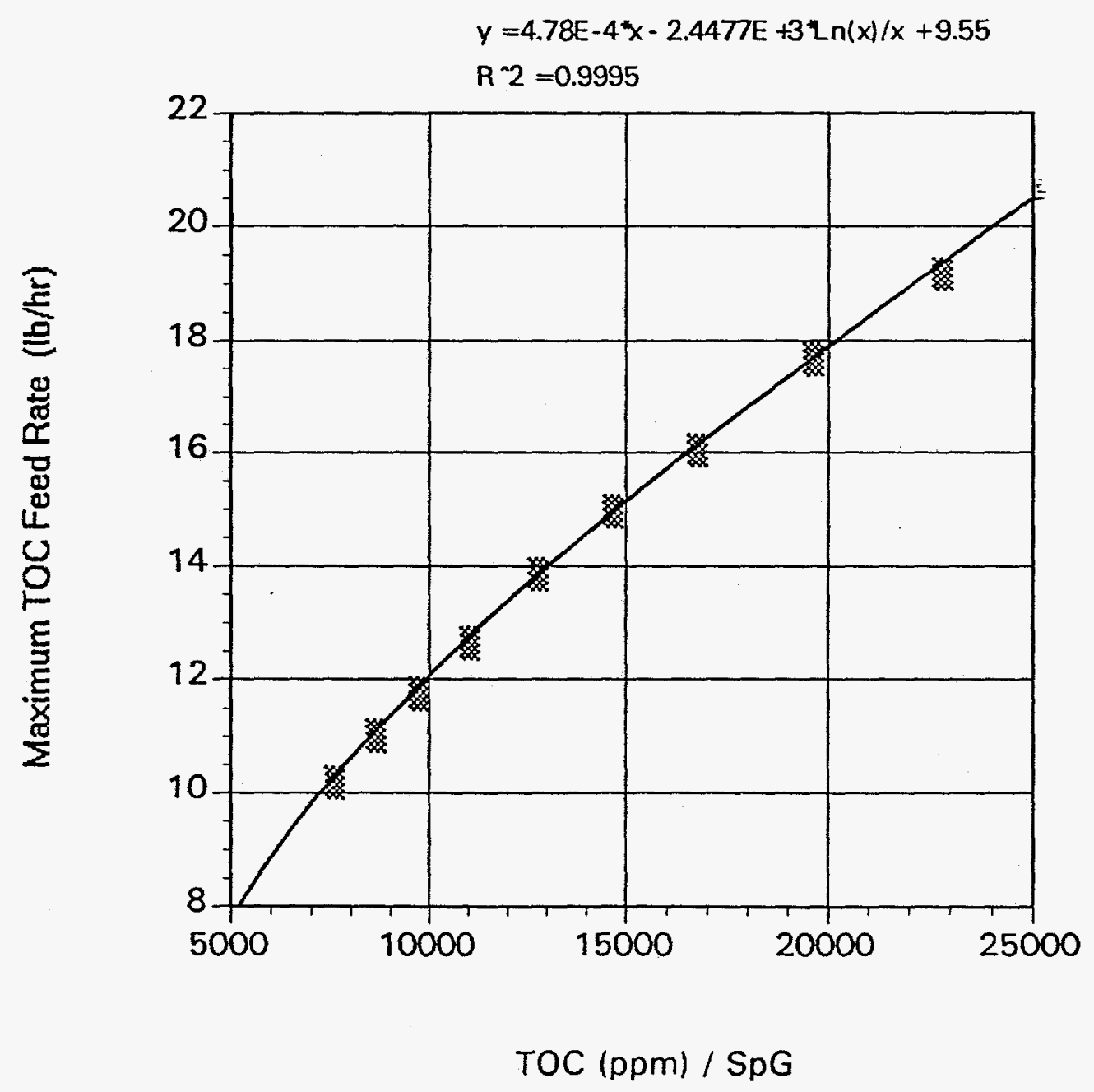

FIGURE 7. Maximum TOC Feed Rate vs. TOC * Specific Gravity 
As shown in Eq. (2), the specific gravities of the feeds with varying TOC levels were estimated in this study based only on the total solids content of the feed, i.e., Eq. (2) will predict the same specific gravity, as long as the total solids content remains unchanged regardless of the ratio of insoluble to soluble solids contents.

In reality, however, the variations in insoluble solids content from one batch of melter feed to the next is small due to tight constraints imposed on many process and operating variables such as the total solids and sodium contents of the sludge feed. For example, the insoluble solids contents of the melter feed samples (MFT$5,6,7)$ ranged from 37.9 to $39.2 \mathrm{wt} \%$. Although the insoluble solids content of the reference feed in Table 1 is a little lower at $35.9 \mathrm{wt} \%$, the application of Eq. (2) to this feed was shown earlier to be valid. However, when the TOC level was purposely increased in this study from the baseline level of $6,820 \mathrm{ppm}$, the insoluble solids contents in the resulting batches became even lower, ranging from 30.0 to $35.9 \mathrm{wt} \%$, since the formates added to increase the TOC level are soluble.

Then, one question might arise from all this; what happens to the validity of the proposed correlations when the actual specific gravity becomes a little lower than that predicted by Eq. (2) at the insoluble solids contents below $35 \mathrm{wt} \%$ ? This can be answered easily from Figures 2, 5 and 7 . Figure 2 shows that at a given feed rate the maximum TOC level increases monotonically as the specific gravity is decreased. So, if Eq. (2) indeed overpredicts the specific gravity at lower insoluble solids contents, the resulting maximum TOC level will be lower than that predicted by using the actual specific gravity. This shows that the maximum TOC limits calculated in this study at low insoluble solids contents are conservative. Figure 5 also shows that at a given TOC level the maximum feed rate increases monotonically as the specific gravity is decreased.

Therefore, the maximum slurry feed rates calculated in this study at low insoluble solids contents are also conservative, since they are lower than those predicted by using the actual specific gravities. Figure 7 also shows the same trend that at a given TOC level the maximum allowable TOC feed rate increases monotonically as the specific gravity is decreased, thus making the calculated maximum TOC feed rates conservative at low insoluble solids contents.

All these discussions thus far have been concerned with the impact of insoluble solids on the specific gravity and, more importantly, on the results of this study, and it was implicitly suggested that the proposed correlations, Eqs. (3) to (5), are valid for slurry feeds containing about 30 to $40 \mathrm{wt} \%$ insoluble solids. It should also be understood that the application of the proposed correlations are generally limited to those operating ranges shown in Table 2 or Figures 2, 5 and 7. 
It should also be noted that the maximum TOC limits or feed rates in Table 2 are the conditions necessary to avoid a potential for forming a flammable vapor in the melter off-gas system, and may not conform to other operating and design criteria. For example, Table 2 shows that up to $35,400 \mathrm{ppm}$ TOC may be tolerated by the melter at $0.7 \mathrm{GPM}$, but the slurry may be too difficult to transfer at the estimated specific gravity of 1.5525 . Table 2 also shows that at 1.5 GPM and a specific gravity of 1.3419 , the estimated glass production rate exceeds the design capacity of $228 \mathrm{lb} / \mathrm{hr}$ by as much as $70 \%$. This indicates that although the feed containing as much as $10,200 \mathrm{ppm}$ TOC can be fed safely at $1.5 \mathrm{GPM}$., the melter will not be able to sustain such a high feed rate for any extended period of time.

\section{PATH FORWARD}

Both the peak intensity and duration of an off-gas surge have a major impact on the calculations of the maximum TOC limit and off-gas flammability. As stated earlier, surges can occur even during carefully controlled operation, and the frequency and characteristics of surges are difficult to predict. So, all the safetyrelated calculations should be based on the worst-case surge scenario. In this study, the $3 \mathrm{X}$ off-gas surge was assumed to have a total duration of 8 minutes with an average flow of $2.25 \mathrm{X}$ normal during the first 1 minute. Although the actual data obtained during recent DWPF melter cold run tests showed that the peak intensity of a surge can be greater than $3 \mathrm{X}$ normal, the observed duration was considerably shorter, only on the order of several seconds. In order to confirm the conservatism in the $3 X$ surge scenario used in this study, the melter off-gas dynamics model will be calibrated using recent DWPF surge data as part of requirements for the Technical Task Request HLW/DWPF/TTR-950047. Once the model is calibrated, the impact of those high-intensity surges with relatively short duration on off-gas flammability will be investigated. 


\section{REFERENCES}

1. Basic Data Report, DPSP-80-1033, Volume 1, April 1985.

2. NFPA 69, Standard on Explosion Prevention Systems, National Fire Protection Association, Inc., February 10, 1992.

3. Choi, A. S., et al, "Summary of Campaigns SGM-9 and SGM-10 of the DWPF Scale Glass Melter," DPST-88-626, December 15, 1988.

4. Choi, A. S., "Material Balance Tables for the DWPF Coupled Feed Flowsheet with Batch One Sludge (U)," WSRC-TR-93-203 (Rev. 0), August 19, 1993.

5. Baich, M. A., et al., "Defense Waste Processing Facility: Technical Bases for HAN Precipitate Hydrolysis Process - I. DWPF Integrated Cold Runs (U)," WSRC-TM-90-11 (Rev. 0), December 1990.

6. Pearson, C. L., "Behavior of Organics during the SRAT/SME Cycle," DPST-87-851, March 17, 1990.

7. Choi, A. S., "Prediction of Melter Off-Gas Explosiveness," WSRC-TR-90-346 (Rev. 0), January 22, 1992.

8. Choi, A. S., "Maximum Total Organic Carbon Limit for DWPF Melter Feed (U)," WSRC-TR-95-0119 (Rev. 0), March 13, $1995 .$.

9. Choi, A. S., "Minimum Air Flow for the DWPF Melter Backup Film Cooler (U)," WSRC-TR-92-376, July 31, 1992.

10. Crow, K. R., "SCM-2 Off-Gas Results for Sludge-Precipitate Feed," DPST-85-575, August 5, 1985.

11. Randall, C. T., and Colven, W. P., "Off-Gas Flow Surges from the Slurry Fed Melter," DPST-82-966, November 1, 1982.

12. Choi, A. S., "Computer Simulation of DWPF Melter Vacuum/Pressure Protection Design Change Proposal (DCP-J-S 93267) - Phase I," WSRC-TR-93-556, December 20, 1993.

13. Choi, A. S., "Phase II Computer Simulation of DWPF Melter Vacuumt Pressure Protection Design Change Proposal (DCP-J-S 93267) (U)," WSRC-TR-94-0154, March 11, 1994. 
14. Jacobs, R. A., "Response to Technical Task Request HLW/DWPF/TTR940013 - Off-Gas LEL Analyzer Performance Improvement (U)," WSRC-RP-94-0924 (Revision 0), September 2, 1994.

15. Hull, H. L., "Trip Report Battelle-Pacific Northwest Laboratory Slurry-Fed Melter Test May 17-21, 1982," DPST-82-718, July 20, 1982.

16. Hull, H. L., "Trip Report Battelle-Pacific Northwest Laboratory Slurry-Fed Melter Test June 14-23, 1982," DPST-82-1008, November 15, 1982. 

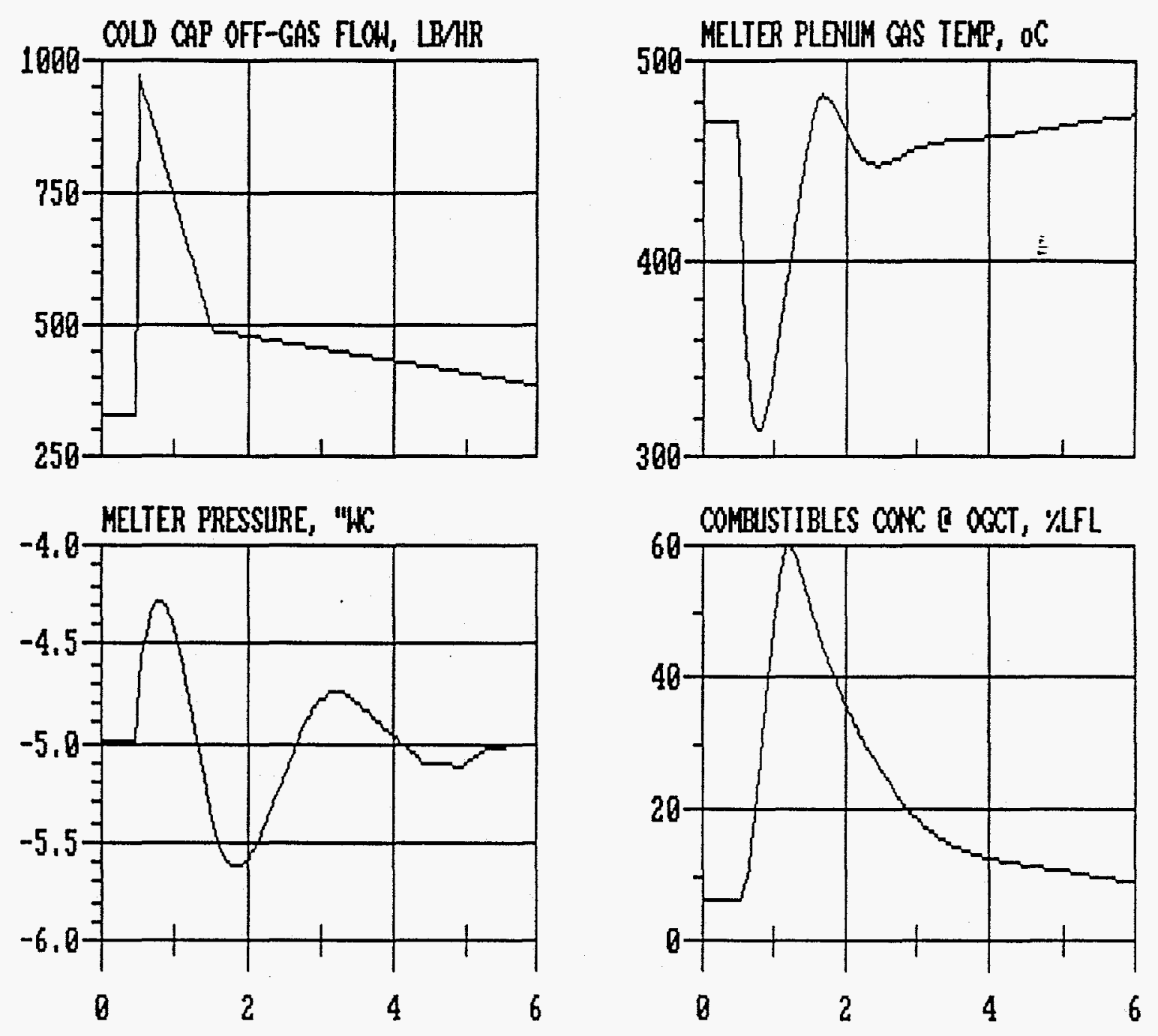

TIME IN MINUTES

FIGURE A-1. 3X Surge Simulation Result (35,400 ppm TOC, 0.7 GPM) 

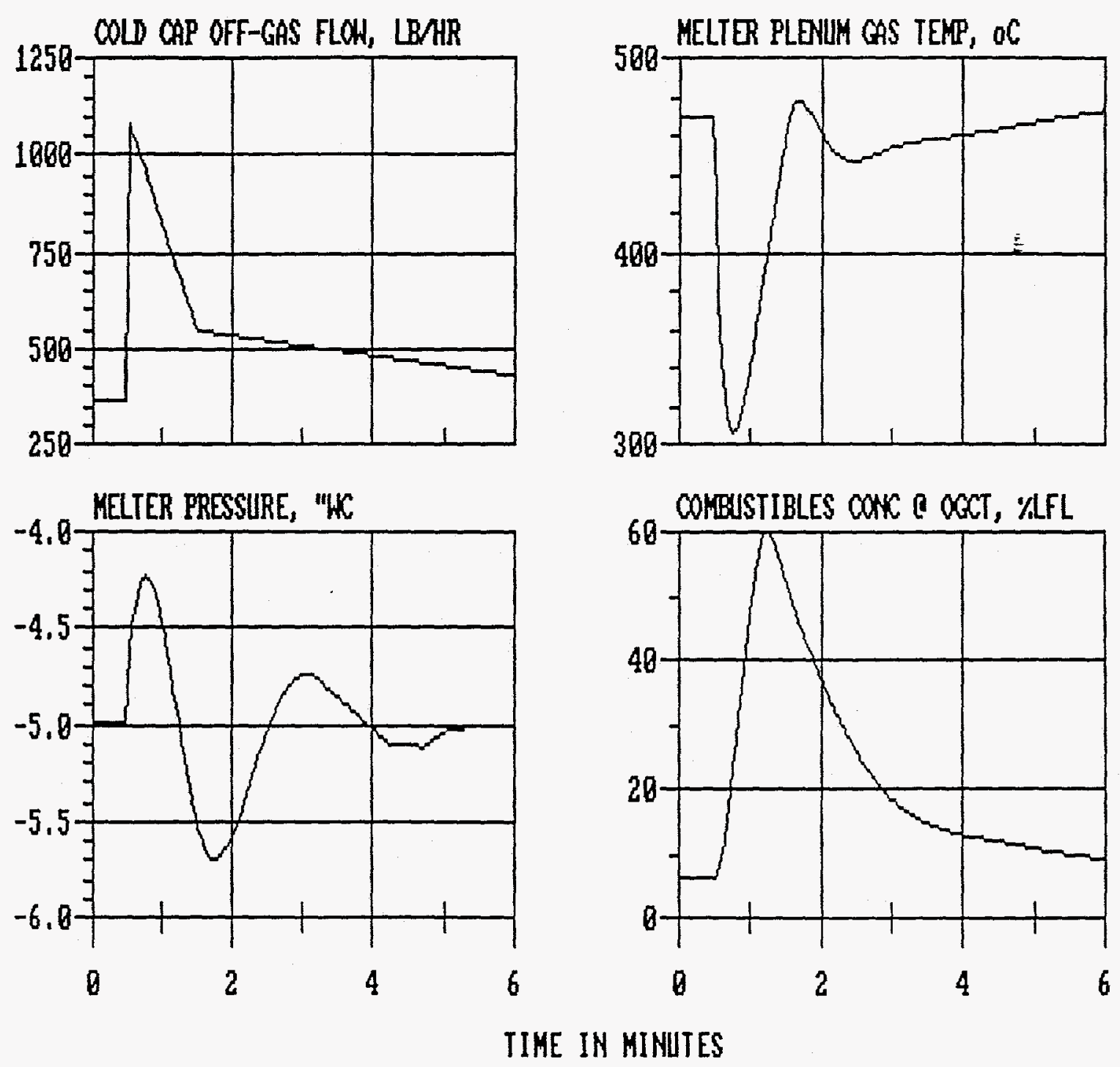

FIGURE A-2. 3X Surge Simulation Result $(29,500 \mathrm{ppm}$ TOC, 0.8 GPM) 

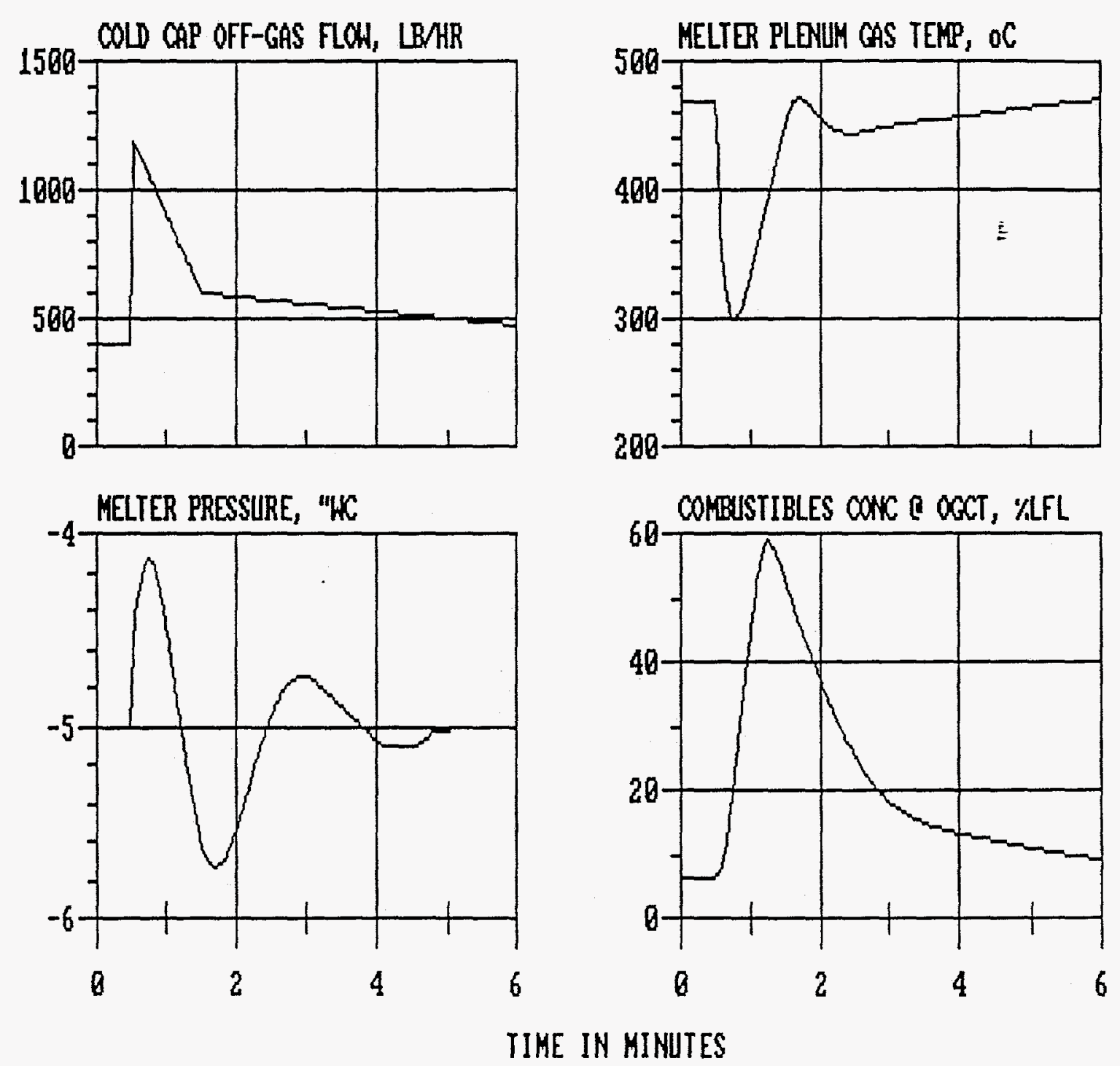

FIGURE A-3. 3X Surge Simulation Result $(24,500$ ppm TOC, 0.9 GPM) 

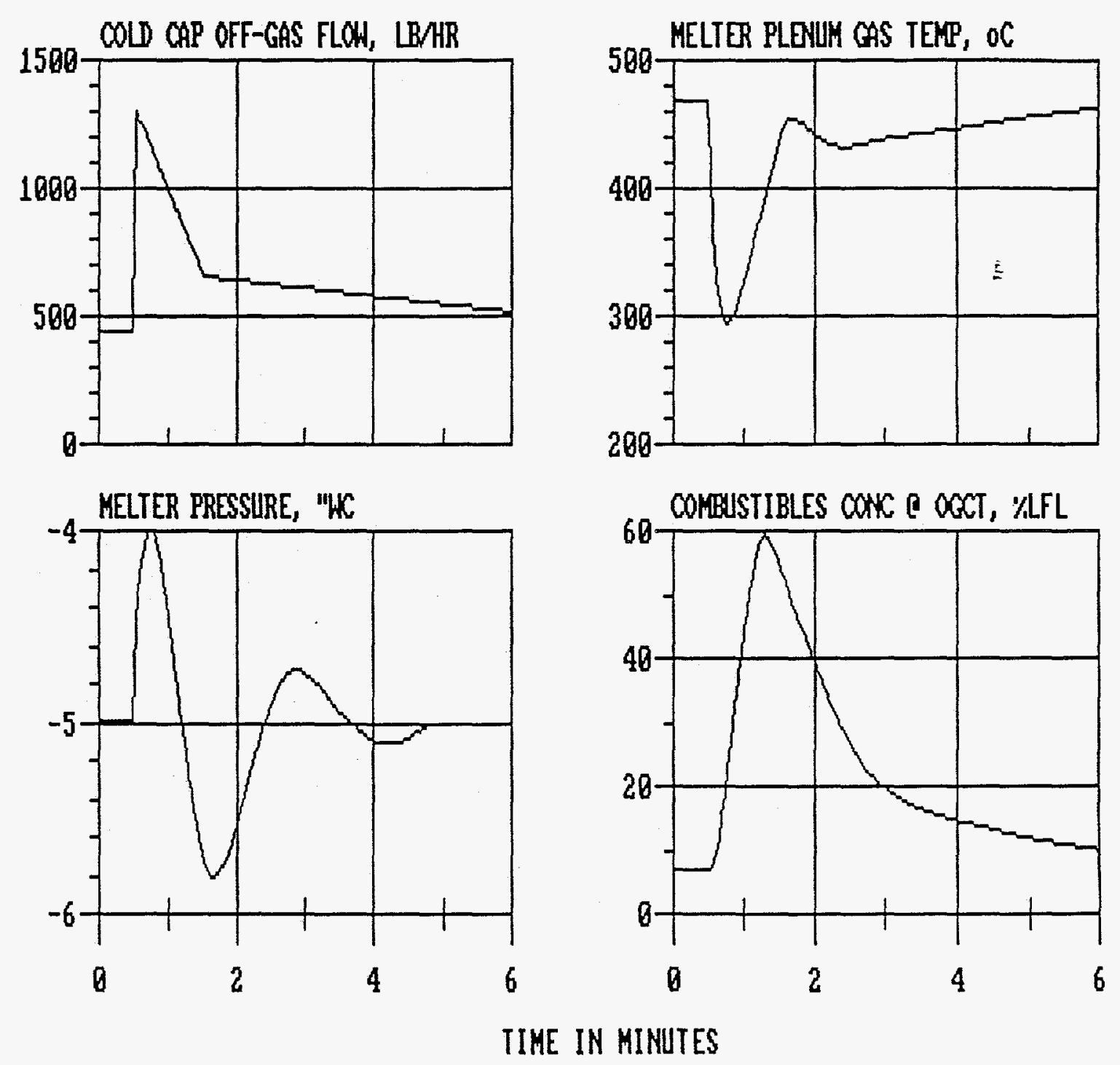

FIGURE A-4. 3X Surge Simulation Result (21,000 ppm TOC, 1.0 GPM) 

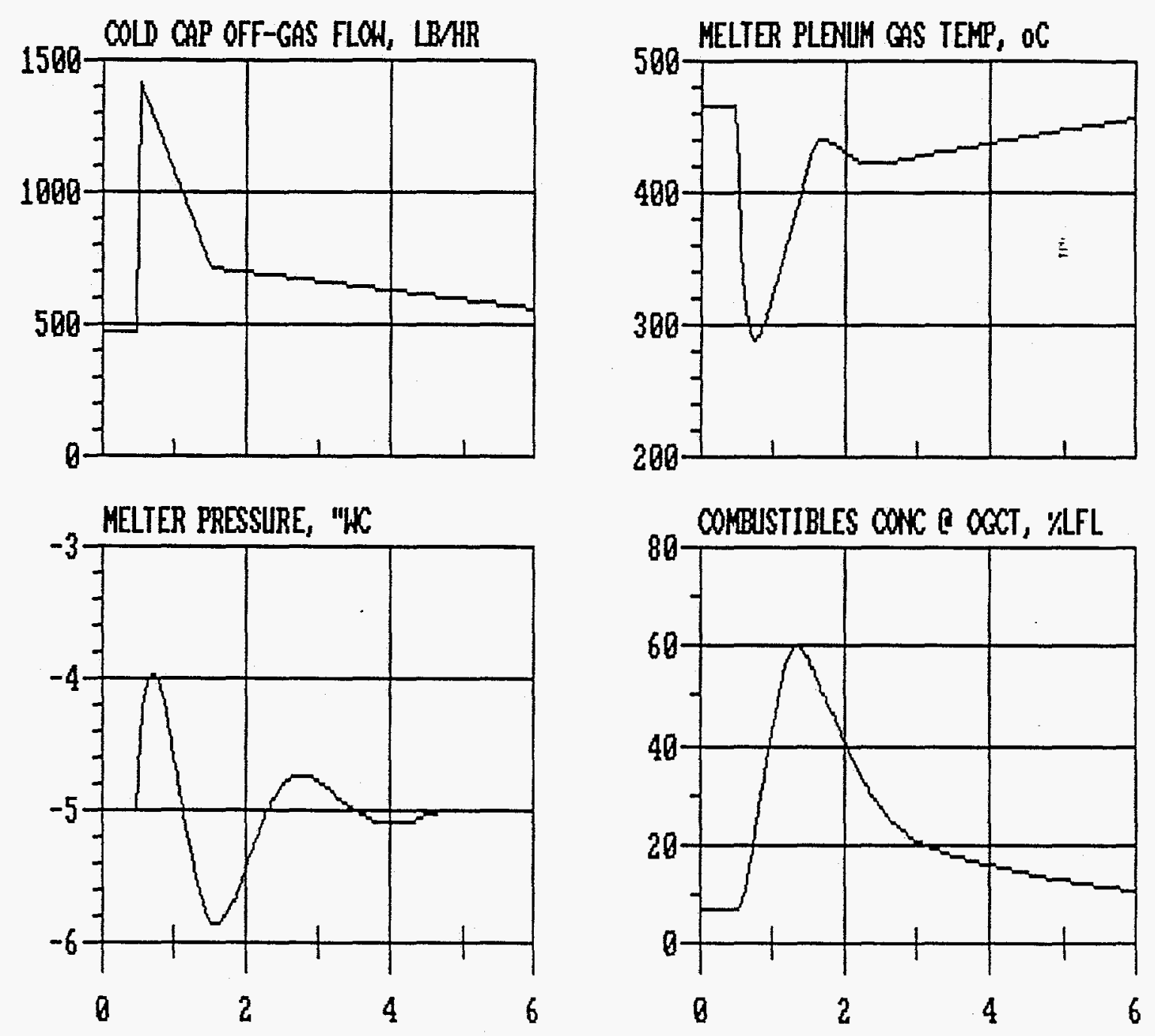

TIME IN MINUTES

FIGURE A-5. 3X Surge Simulation Result (18,000 ppm TOC, 1.1 GPM) 

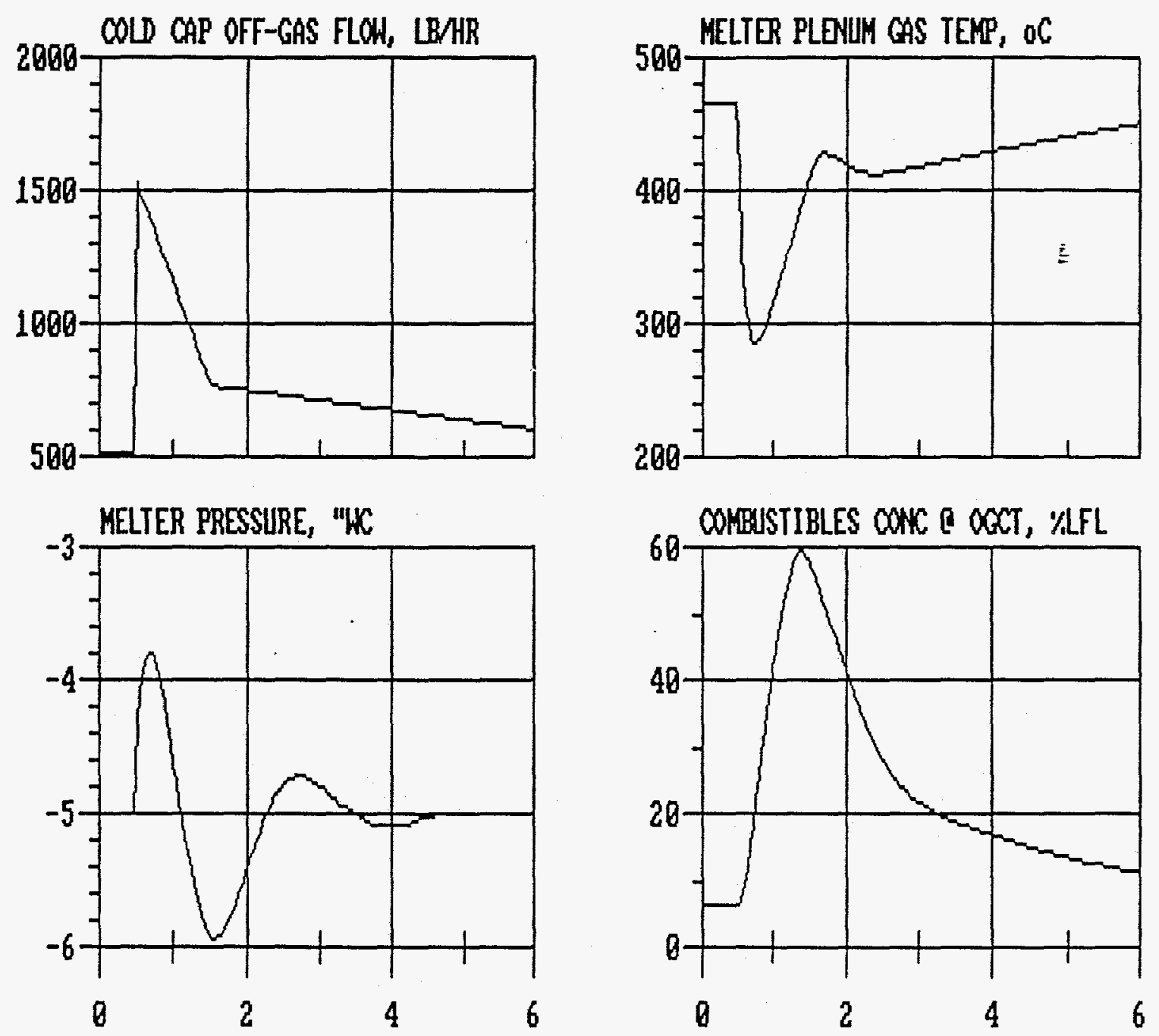

TIME IN MINUTES

FIGURE A-6. $3 X$ Surge Simulation Result $(15,300 \mathrm{ppm}$ TOC, 1.2 GPM) 

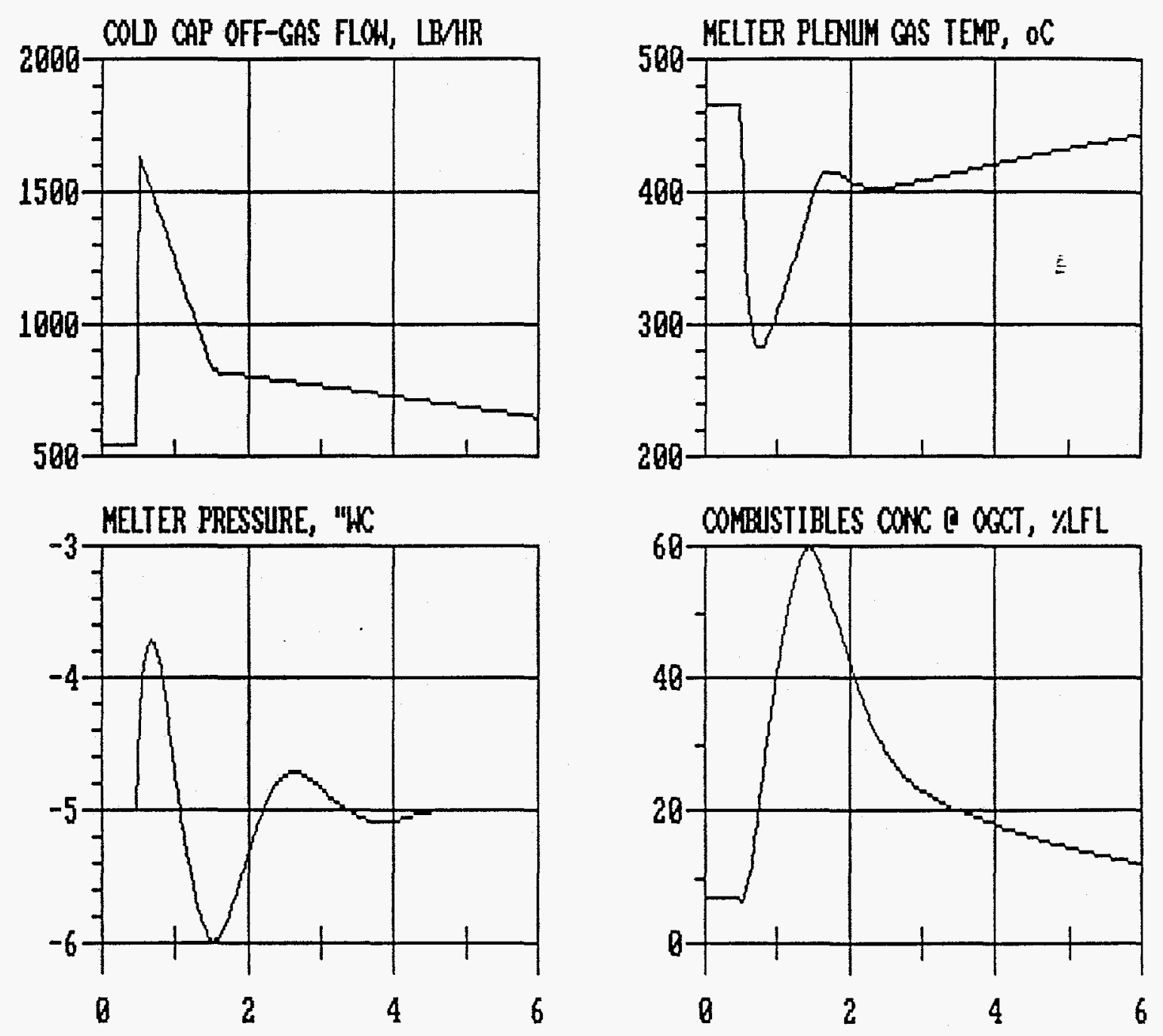

TIME IN MINUTES

FIGURE A-7. 3X Surge Simulation Result $(13,300$ ppm TOC, 1.3 GPM) 

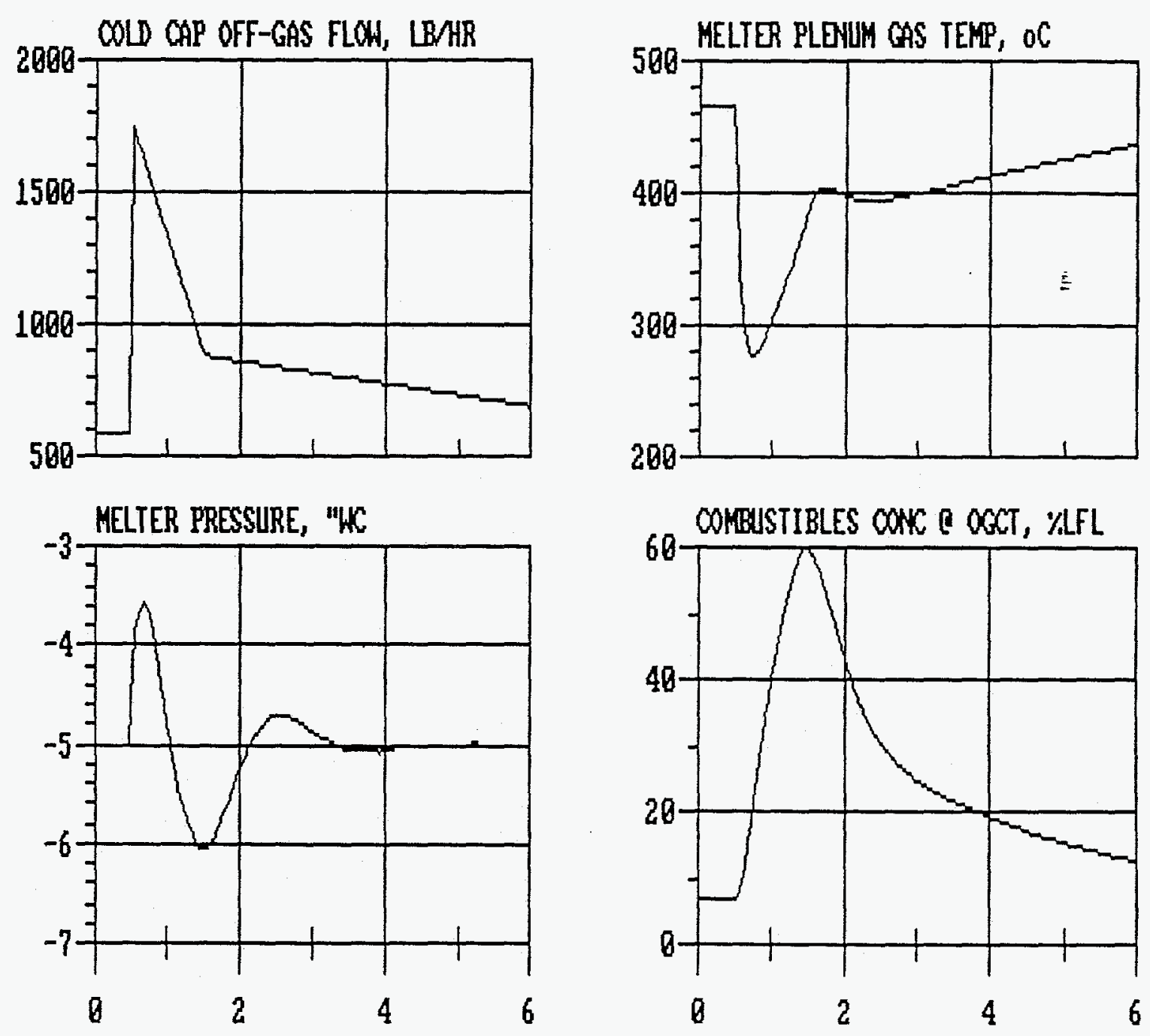

TIME IN MINUTES

FIGURE A-8. 3X Surge Simulation Result $(11,700$ ppm TOC, 1.4 GPM) 

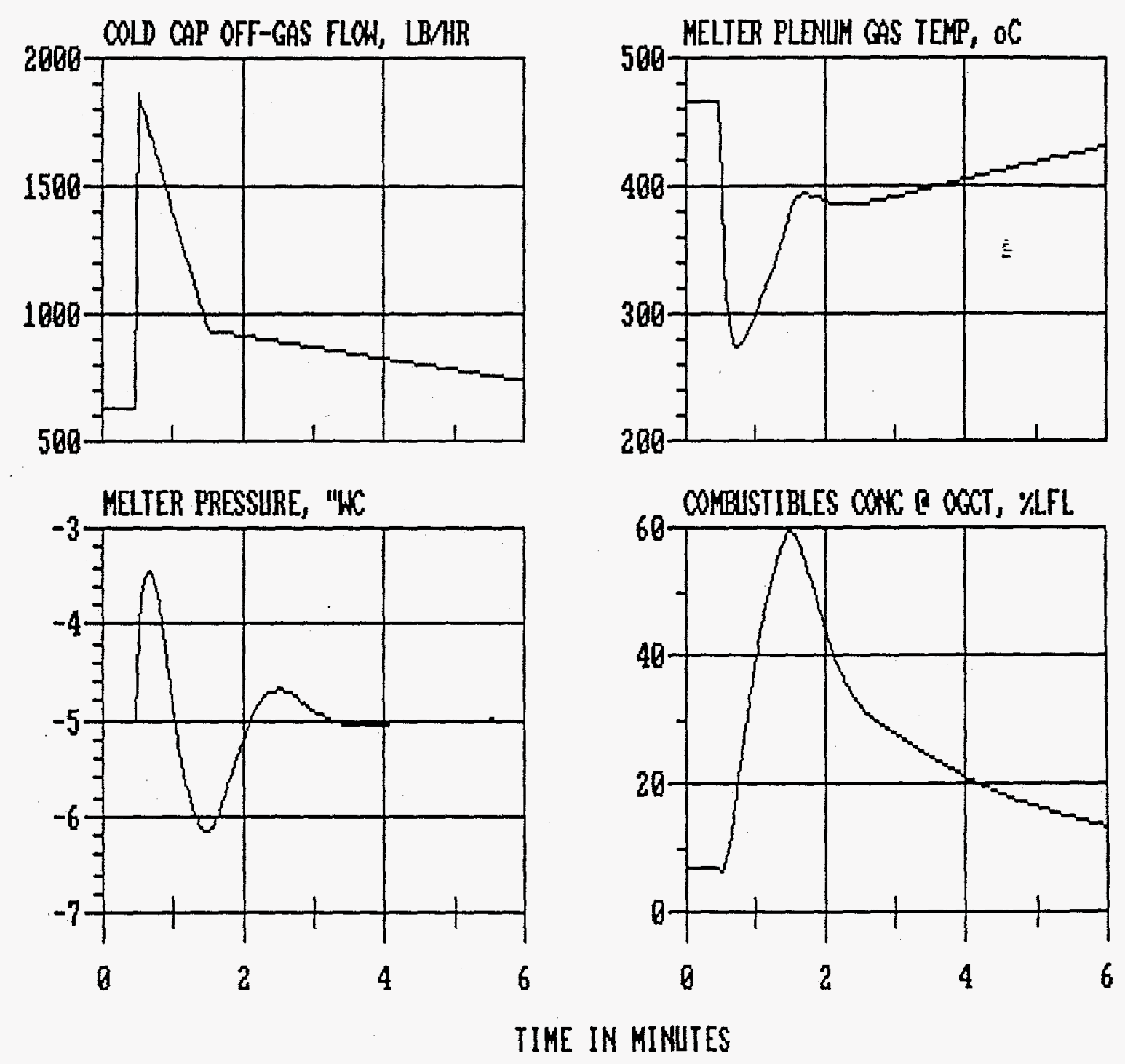

FIGURE A-9. 3X Surge Simulation Result $(10,200 \mathrm{ppm}$ TOC, 1.5 GPM) 